\title{
Zircon Chemistry and Oxidation State of Magmas for the Duobaoshan-Tongshan Ore-Bearing Intrusions in the Northeastern Central Asian Orogenic Belt, NE China
}

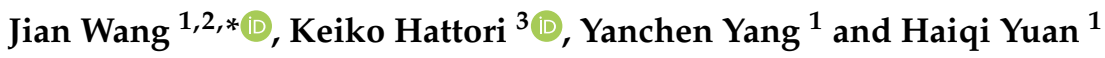 \\ 1 College of Earth Sciences, Jilin University, Changchun 130061, China; yyc@jlu.edu.cn (Y.Y.); \\ yuanhq18@mails.jlu.edu.cn (H.Y.) \\ 2 Key Laboratory of Mineral Resources Evaluation in Northeast Asia, Ministry of Natural Resources of China, \\ Changchun 130026, China \\ 3 Department of Earth and Environmental Sciences, University of Ottawa, Ottawa, ON K1N 6N5, Canada; \\ khattori@uottawa.ca \\ * Correspondence: wangjian304@jlu.edu.cn
}

Citation: Wang, J.; Hattori, K.; Yang, Y.; Yuan, H. Zircon Chemistry and Oxidation State of Magmas for the Duobaoshan-Tongshan Ore-Bearing Intrusions in the Northeastern Central Asian Orogenic Belt, NE China. Minerals 2021, 11, 503. https://doi.org/10.3390/ $\min 11050503$

Academic Editors: Hans-Jürgen Gawlick, Michał Krobicki and Laszlo Bujtor

Received: 2 April 2021

Accepted: 4 May 2021

Published: 10 May 2021

Publisher's Note: MDPI stays neutral with regard to jurisdictional claims in published maps and institutional affiliations.

Copyright: (c) 2021 by the authors. Licensee MDPI, Basel, Switzerland. This article is an open access article distributed under the terms and conditions of the Creative Commons Attribution (CC BY) license (https:/ / creativecommons.org/licenses/by/ $4.0 /)$.

\begin{abstract}
The Duobaoshan (DBS)-Tongshan (TS) porphyry Cu-(Mo) deposit (4.4 Mt Cu, 0.15 Mt Mo) is located in the northeastern part of the central Asian orogenic belt (CAOB) in northeastern China. It is hosted by early Ordovician dioritic to granodioritic intrusions which are characterized by the subduction-related geochemical signatures including high concentrations of large ion lithophile elements (LILEs) and light rare earth elements (LREEs), and low concentrations of heavy REEs (HREEs) and high-field -strength elements (HFSEs), such as $\mathrm{Nb}, \mathrm{Ta}, \mathrm{Zr}$ and $\mathrm{Ti}$ in bulk rock compositions. Furthermore, they show adakitic geochemical signatures of high Sr/Y ratios (29 55) due to high Sr (290 750 ppm) and low Y (<18 ppm). Zircon trace element abundances and published Sr-Nd-Hf isotope data of these rocks suggest that the parental magmas for these ore-bearing intrusions were rich in $\mathrm{H}_{2} \mathrm{O}$ and formed by partial melting of a juvenile lower crust/lithospheric mantle or metasomatized mantle wedge during the northwestward subduction of the Paleo-Asian Ocean before the collision of the Songnen block with the Erguna-Xing'an amalgamated block in the early Carboniferous. Values of $\mathrm{Ce}^{4+} / \mathrm{Ce}^{3+}$ and $\mathrm{Ce} / \mathrm{Nd}$ in zircons are 307 461 and 14.1 20.3 for mineralized granodiorites, and 231 350 and 12.4 18.2 for variably altered diorite and granodiorites in DBS, whereas those for DBS-TS microgabbros are 174 357 and 7.4 22, and 45.9 62.6 and 5.0 5.8 for the early Mosozoic Qz-monzonites, respectively. Zircon $\mathrm{Eu} / \mathrm{Eu}^{*}$ values are high and similar among mineralized granodiorites ( 0.6), altered diorite and granodiorites ( $\sim 0.6)$ and the Mesozoic Qz-monzonites $(\sim 0.8)$, whereas the values are low and variable for the DBS-TS microgabbros (0.3 0.6). The magma oxidation state calculated from zircon chemistry and whole rock compositions are FMQ +1.0 to +1.5 in mineralized samples, and FMQ +2.4 to +4.2 in altered samples. The values are comparable to those for the fertile intrusions hosting porphyry $\mathrm{Cu}-\mathrm{Mo}-(\mathrm{Au})$ deposits in the central and western $\mathrm{CAOB}$ and elsewhere in the world. Elevated oxidation state is also observed in the TS microgabbros, FMQ +1.4 to +1.9 , and the early Mesozoic Qz-monzonites, FMQ +2.4 to +2.5 . Comparison of zircon geochemistry data from porphyry deposists elsewhere suggests that positive Ce anomalies are generally associated with fertile intrusions, but not all igneous rocks with high $\mathrm{Ce}$ anomalies are $\mathrm{Cu}$ fertile. The findings in this study are useful in exploration work and evaluating oxidation state of magmas for porphyry $\mathrm{Cu}-(\mathrm{Mo})$ deposits in the region and elsewhere.
\end{abstract}

Keywords: magma fertility; porphyry $\mathrm{Cu}-(\mathrm{Mo})$ deposit; ore-bearing intrusion; zircon trace elements; Ce and Eu anomalies; magma oxidation state

\section{Introduction}

The Great Xing'an Range in northeastern China is characterized by abundant granitic rocks associated with $\mathrm{Cu}, \mathrm{Mo}, \mathrm{Au}$, and $\mathrm{Pb}-\mathrm{Zn}$ deposits [1-4]. The vast majority of these 
granites and related deposits formed in Mesozoic and Cenozoic during the subduction of the Mongolia-Okhotsk Oceanic plate [5-9] and the Paleo-Pacific Oceanic plate below the eastern part of CAOB $[10,11]$. Early Paleozoic granitoids are rare in the northern Great Xing'an Range except those in the DBS-TS ore field [12,13] (Figure 1a,b; [14-18]). Thus, the DBS-TS deposit and its hosting granitoids provide valuable information in deciphering metallogenetic characteristics in early Paleozoic period. Previous studies on the DBS-TS deposit mainly focused on (1) geology, geochemistry, geochronology and petrogenesis of the ore-hosting intrusions and country rocks (e.g., [11,13,19-26]), and (2) metallogenesis $[11,23,27]$. However, the source of these ore-bearing porphyry intrusions and their geodynamic settings are still in debate [12,23-26,28].

The oxidation state of parental magmas is important for the formation of porphyry $\mathrm{Cu}-\mathrm{Mo}-(\mathrm{Au})$ deposits because oxidized magmas are capable of supplying metals and $\mathrm{S}$ from magma sources to ore deposits (e.g., $[29,30])$. Cerium can be $\mathrm{Ce}^{4+}$ in oxidized magmas among rare earth elements (REE). Zircon, $\mathrm{ZrSiO}_{4}$, crystallizing in oxidized magmas easily incorporates $\mathrm{Ce}^{4+}$ to produce positive anomalies of $\mathrm{Ce}$ in the abundances of REEs (e.g., [16,31-33]). Trace element geochemistry of zircon has been carried out for many porphyry Cu-Mo deposits in the world in recent years (e.g., [34-41]), but studies on early Paleozoic deposits are not many, and this is the first systematic study on oxidation state of the early Paleozoic DBS-TS porphyry Cu-Mo deposit in eastern CAOB.

Cerium anomaly is generally expressed as $\mathrm{Ce}_{n} /\left(\mathrm{La}_{n} \times \mathrm{Pr}_{n}\right)^{1 / 2}$. As the concentrations of La in zircon are low, commonly below or around the detection limit of analytical instruments, several different expressions of $\mathrm{Ce}$ anomalies are proposed: $\mathrm{Ce}^{4+} / \mathrm{Ce}^{3+}[31]$, $\mathrm{Ce} / \mathrm{Nd}$ [42], and $\mathrm{Ce} / \mathrm{Ce}^{*}=\mathrm{Ce}_{\mathrm{n}} /\left(\mathrm{Nd}_{\mathrm{n}}{ }^{2} / \mathrm{Sm}_{\mathrm{n}}\right)$ [43]. In addition, calculation of Ce/Ce* using all REE was proposed by Zhong et al. [38] and Lee et al. [37]. These parameters are broadly positively correlated [44]). Values of $\mathrm{Ce} / \mathrm{Ce}^{*}$ and $\mathrm{Ce} / \mathrm{Nd}$ can be directly obtained from zircon compositions. Recently, Smythe and Brenan [45,46] and Loucks et al. [47] proposed empirical equations to calculate $f \mathrm{O}_{2}$ based on zircon compositions.

Previous studies show that zircons from fertile intrusions associated with porphyry $\mathrm{Cu}-\mathrm{Mo}$ mineralization contain high concentrations of $\mathrm{Ce}$ with variably high $\mathrm{Ce}^{4+} / \mathrm{Ce}^{3+}$ values, reflecting oxidized conditions of the parental magmas, and that zircons from barren (not associated with metal mineralization) intrusions contain low $\mathrm{Ce}^{4+} / \mathrm{Ce}^{3+}$ values (e.g., $[16,31,32,48])$. Some workers consider the magnitude of the $\mathrm{Ce}$ and/or Eu anomalies to be related to the size (Cu or Mo tonnage) or grade of deposits $[16,18,31,44,49]$. This paper examines whether the fertility is related to $\mathrm{Ce}$ and $\mathrm{Eu}$ anomalies of zircon and whether Ce anomalies are associated with highly oxidized magmas based on the data from the DBS-TS deposit.

This contribution presents trace element abundances of zircon and bulk rocks from the DBS-TS deposit, evaluates the oxidation state of parental magmas, and discusses their origins and evolution, and tectonic setting. The results from the DBS-TS deposit are compared with the data from other well-known porphyry $\mathrm{Cu}-\mathrm{Mo}$ deposits elsewhere in the world. 

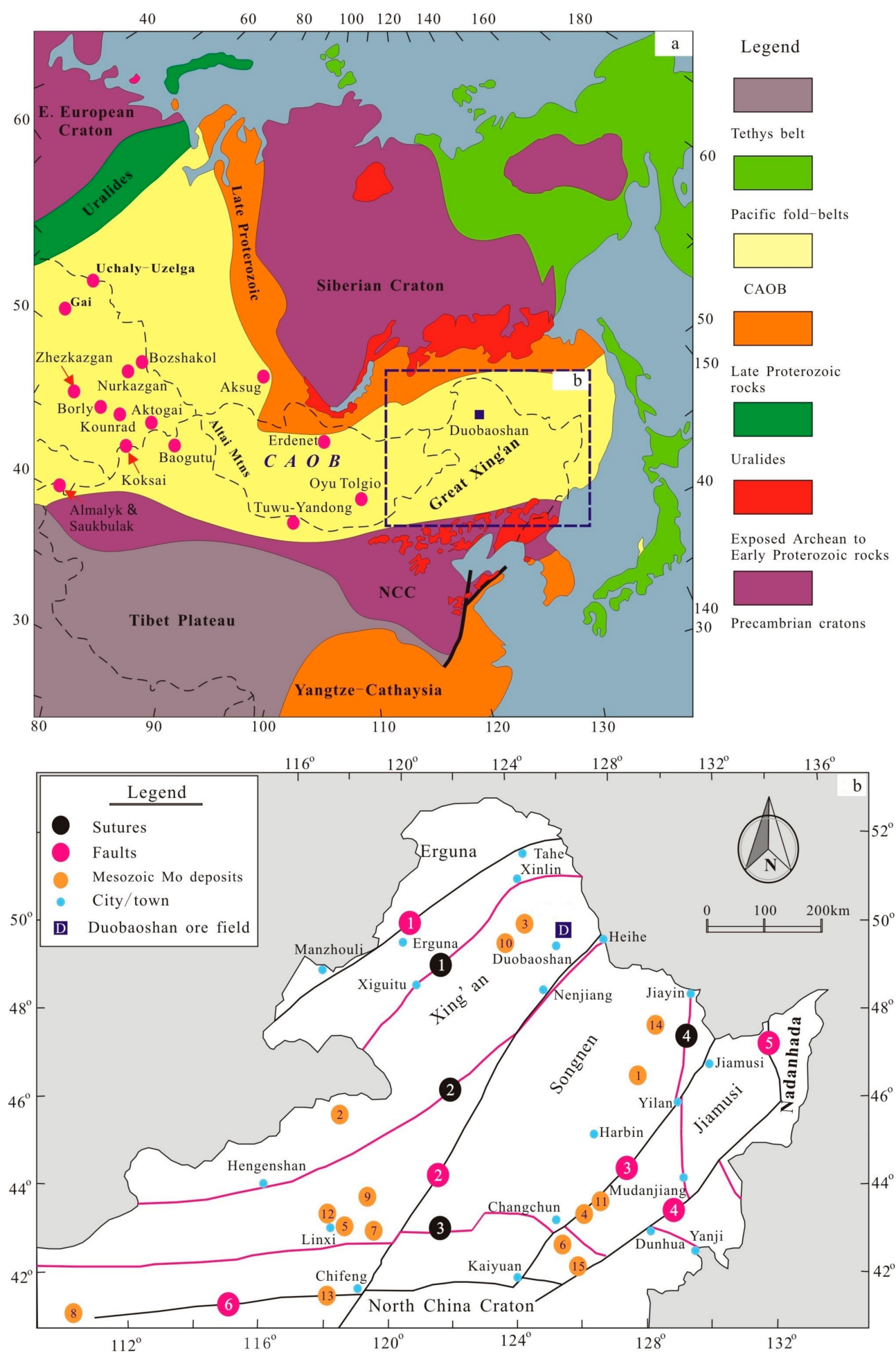

Figure 1. (a) Tectonic map of the CAOB and location of the DBS-TS porphyry Cu-Mo deposit (modified after [14]). (b) Tectonic framework of NE China (after [15]). Other porphyry Cu-Mo-(Au) deposits in CAOB are also shown in Figure 1a (data source: $[16,17])$. In (b), black circles with numbers in are sutures $(1=$ Xinlin-Xiguitu, $2=$ HegenshanHeihe, 3 = Solonker-Xar Moron-Chandchun-Yanji, 4 = Mudanjiang-Yilan); pink circles with numbers are regional faults ( 1 = Derbugan, 2 = Nenjiang-Balihan, 3 = Jiamusi-Yilan, 4 = Dunhua-Mishan, 5 = Yujinshan, 6 = Chifeng-Kaiyuan); orange circles with numbers are Mesozoic porphyry Mo deposits in NE China $(1=$ Chalukou, $2=$ Caosiyao $3=$ Daheishan 4 = Luming, 5 = Diyanqin'amu, 6 = Jidetun, 7 =Xing'a, 8 = Fu'anpu, $9=$ Dasuji, $10=$ Hashitu, $11=$ Chehugou, $12=$ Hutulu, 13 = Yangchang, 14 = Haisugou, 15 = Shabutai; data source: [18]). 


\section{General Geology}

The CAOB, located between the Siberian, North China, and Tarim cratons, is the largest accretionary belt in the world and formed through multiple subductions and accretions in a period of 800 m.y. (Figure 1a; [14,50-53]). The northeastern part of CAOB formed primarily through the subduction of the Paleo-Asian Oceanic plate and the accretion of several micro-continents including the Erguna, Xing'an, Songnen, Jiamusi, and Khanka blocks (Figure 1b; [15,54-59]).

Regarding the geodynamic setting for the Ordovician magmatism including the hosting intrusions of the DBS-TS Cu-Mo deposit in the study area, three models have been proposed: (1) collision or post-collision of the Erguna and Xing'an block after northwestward subduction of the Xing'an block (Figure 1b; [12,13,28]), (2) post-collision of the Erguna-Xing'an block and Songnen block [19,60], and (3) subduction related island arc or continental arc [21,23].

The $\mathrm{CAOB}$ has a number of porphyry $\mathrm{Cu}-\mathrm{Mo}-(\mathrm{Au})$ deposits including the giant $\mathrm{Oyu}$ Tolgoi deposit in Mongolia (>42 Mt Cu and $1850 \mathrm{t} \mathrm{Au} \mathrm{[17])} \mathrm{and} \mathrm{Kalmakyr-Dalnee} \mathrm{deposit}$ in Uzbekistan (>22 Mt Cu and >3644 $\mathrm{t} \mathrm{Au} \mathrm{[61])} \mathrm{and} \mathrm{small} \mathrm{Borly} \mathrm{deposit} \mathrm{in} \mathrm{Kazakhstan}$ $(0.6 \mathrm{Mt} \mathrm{Cu})$ and Baogutu deposit in China $(0.6 \mathrm{Mt} \mathrm{Cu})[18,60]$. Porphyry Cu-Mo-(Au) mineralization in CAOB spans from late Cambrian (e.g., Bozshakol deposit) to early Triassic (e.g., Erdenet deposit) [61].

The area of DBS in the Xing'an block of the eastern CAOB hosts several Cu-Mo-(Au) deposits including two Paleozoic deposits (DBS and TS) and three Mesozoic deposits (Figures 1a,b and 2). Mesozoic deposits are two skarn type Fe-Cu deposits at Sankuanggou and Xiaoduobaoshan and an epithermal Au deposit at Zhengguang (Figure 2 [8]). These Mesozoic deposits are considered to have been formed during the subduction of the Mongolia-Okhotsk Oceanic plate [5-8] or the Paleo-Pacific Oceanic plate [10,11].

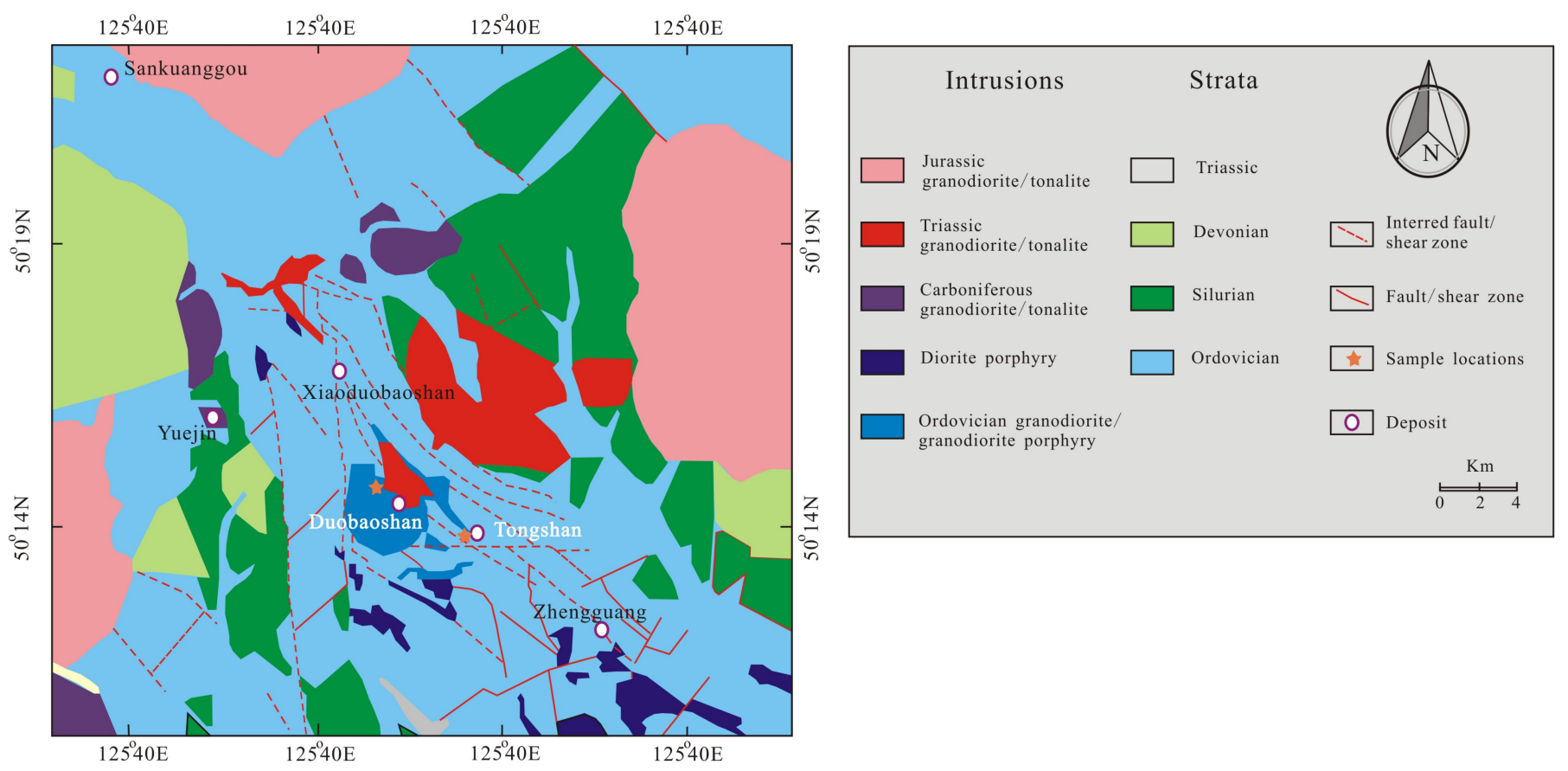

Figure 2. Simplified geological map of the DBS ore field (modified after $[23,25]$ ).

The DBS-TS deposit, with proved reserves of $4.4 \mathrm{Mt} \mathrm{Cu}$ and $0.15 \mathrm{Mt} \mathrm{Mo}$, is the third largest porphyry $\mathrm{Cu}-(\mathrm{Mo})$ deposit in the eastern part of $\mathrm{CAOB}$ after the Oyu Tolgoi and Erdenet ( $>11 \mathrm{Mt} \mathrm{Cu}$; [61]) deposits. The deposit is hosted by the early Ordovician porphyritic diorite or granodiorite (Figure 2). U-Pb zircon age for the DBS hosting granodioritic porphyries is 477 482 Ma [23] and $475.9 \pm 0.8 \mathrm{Ma}$ [11] for the TS hosting granodiorite. The Re-Os isochron age of molybdenite grains for the DBS deposit is $475.9 \pm 7.9$ Ma by Zeng 
et al. [23], and $473 \pm 4$ Ma by Hao et al. [11] for the TS deposit, confirming the association of granodiorite magmatism with the mineralization.

\section{Geology of the DBS-TS Area}

The DBS-TS ore-bearing magmas intruded the Duobaoshan Formation and Tonshan Formation, which is composed mainly of tuffaceous siltstone, tuff, andesite and basalt ([11] Figure 2). The host rocks for the DBS-TS deposit are composed of granodiorite, granodioritic porphyry and diorite with minor microgabbro (Figure 3a-d).

Granodiorite shows medium- to coarse-grained hypidiomorphic-granular and granitic textures and consists of plagioclase (50 70 vol.\%), K-feldspar (5 15 vol.\%), quartz (10 20 vol.\%), hornblende (5 10 vol. \%) and minor biotite ( $0 \sim 5$ vol. $\%$; Figure 3b,c,e,f). Plagioclase shows albite twins and is variably altered to clinozoisite. Hornblende and biotite are altered to chlorite, epidote, and magnetite (Figure 3e,f). Accessory minerals include apatite, zircon, titanite and magnetite. There are no essential differences in mineralogy between mineralized and altered granodiorites except that mineralized rocks contain chalcopyrite and pyrite (Figure $3 b$ ).

Microgabbro occurs as dykes (10 20 $\mathrm{m}$ in width) cutting the granodioritic intrusion in DBS deposit or as rocks intruded by the granodioritic to dioritic rocks in the TS deposit. It shows porphyritic texture with clinopyroxenes as the main phenocrysts (15 20 vol.\%) in the matrix of fine-grained granular clinopyroxene and plagioclase (Figure 3d,g). Grains of clinopyroxene are variably altered to chlorite, epidote and magnetite in the TS samples. Primary magnetite grains are present in some microgabbros.

Quartz monzonite occurs as small intrusions $(<100 \mathrm{~m}$ in diameter) within the Duobaoshan granodioritic to dioritic host (Figure $3 \mathrm{a}, \mathrm{h}$ ). It is barren and shows mediumgrained granitic texture and consists of plagioclase (40 50 vol.\%), K-feldspar (20 30 vol.\%), quartz (15 20 vol.\%) and muscovite (5 10 vol.\%) (Figure 3h). Accessory mineral includes apatite, zircon and magnetite.
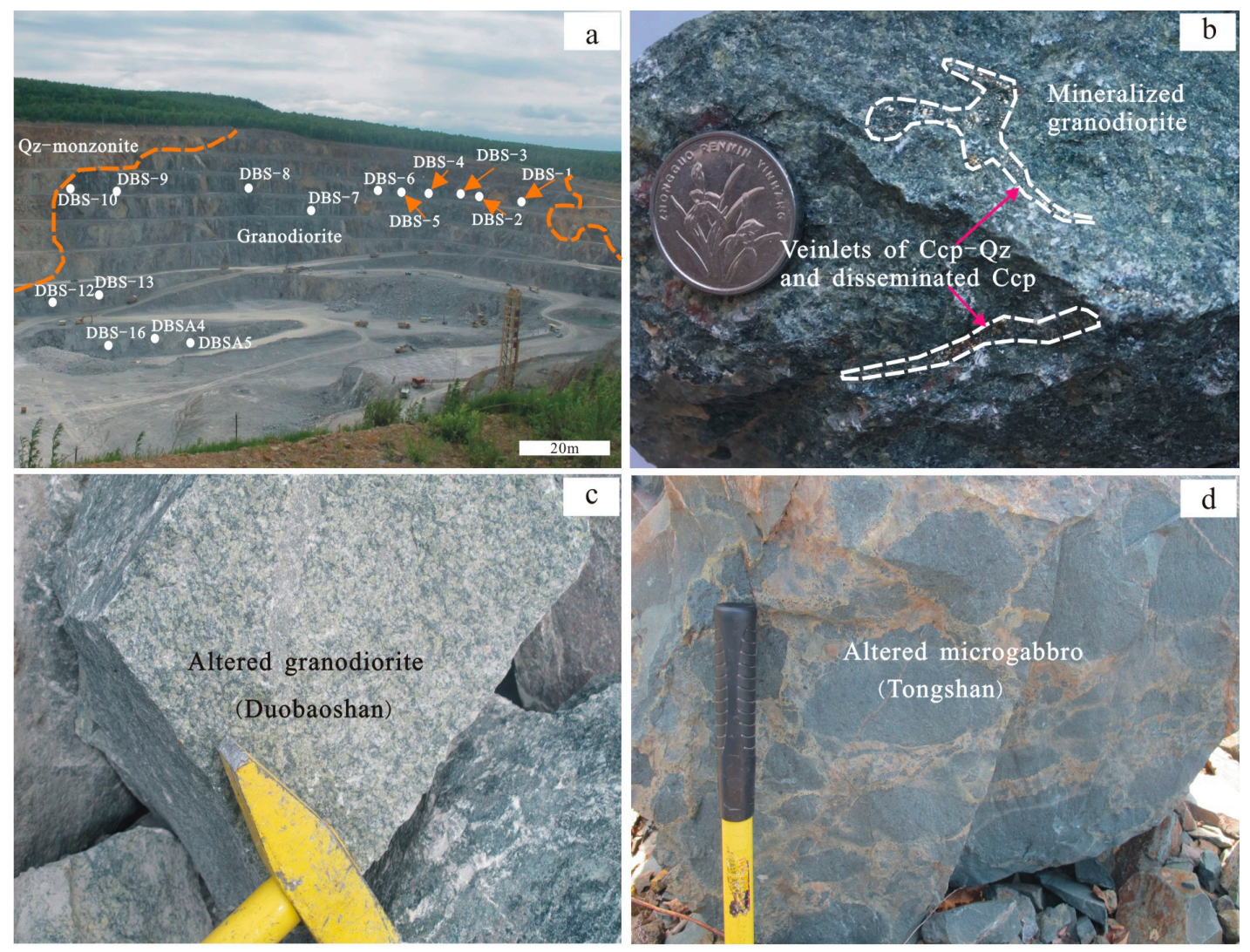

Figure 3. Cont. 


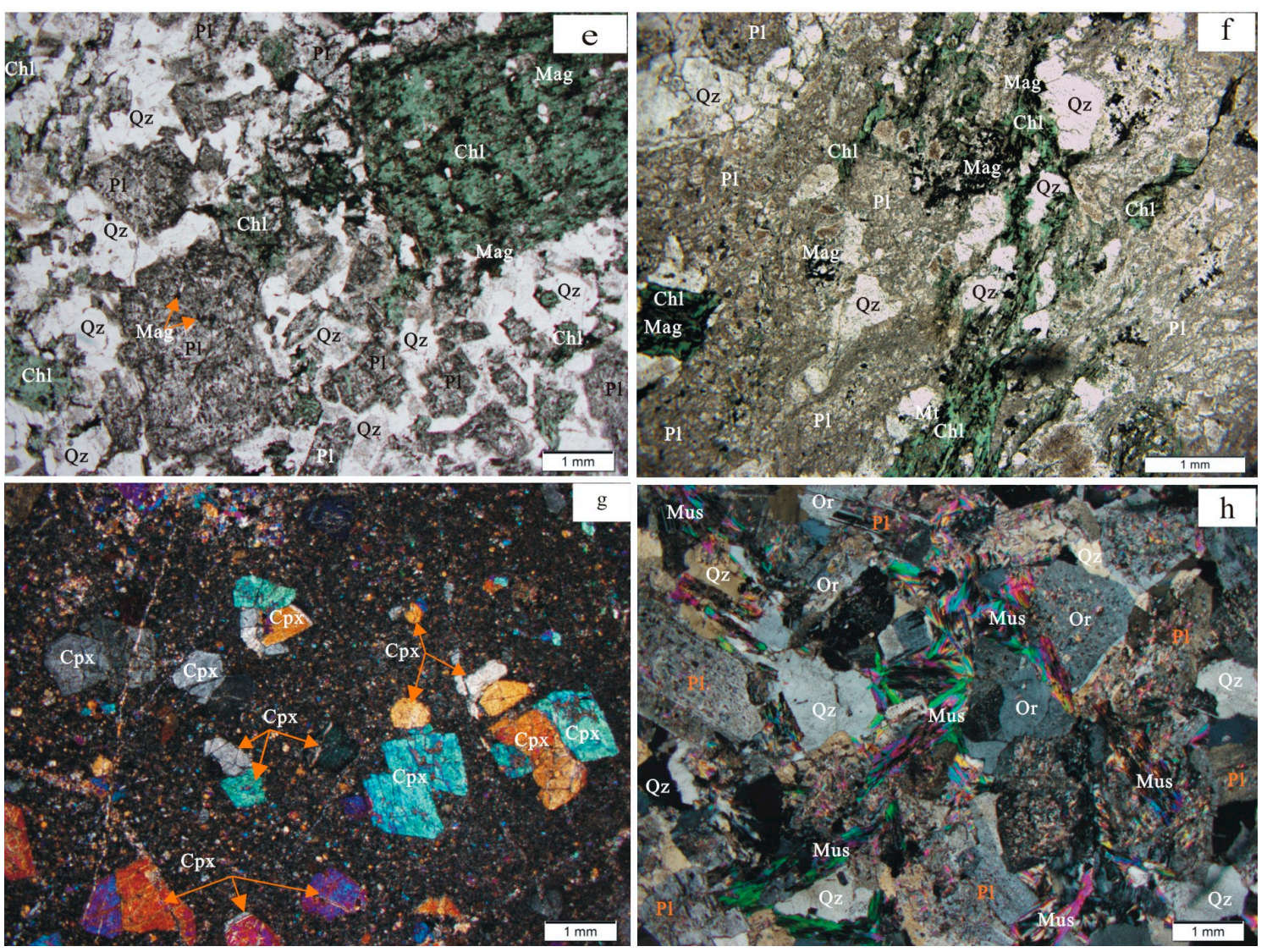

Figure 3. (a) The DBS open pit showing intrusive contacts between the Ordovician granodiorite and the Mesozoic quartzmonzonite. Note that white solid circles with orange arrows are sampling sites. (b) Photograph of a mineralized granodiorite with narrow chalcopyrite-quartz veinlets and disseminated chalcopyrite and propylitic alteration. (c) Photograph of a typical granodiorite with strong propylitic alteration and earlier weak potassic alteration. (d) Photograph of a typical microgabbro with moderate propylitic alteration. (e) Photomicrograph of an altered porphyritic granodiorite (sample DBS1) with altered plagioclase (Pl) and hornblende pseudomorphically replaced by chlorite (Chl) and magnetite (Mag). (f) Photomicrograph of a mineralized granodiorite (sample DBS16). Note that the aggregates of green chlorite, epidote (Ep) and magnetite (Mag) replace primary hornblende. (g) Photomicrograph of a microgabbro (sample DBS7) containing phenocrysts of clinopyroxene $(\mathrm{Cpx})$ in the groundmass of fine-grained plagioclase and clinopyroxene. (h) Photomicrograph of a quartz-monzonite (sample DBSA1) containing coarse-grained orthoclase (Or), plagioclase (Pl), biotite (Bi), and muscovite (Mus).

Alteration in the DBS-TS porphyry Cu-Mo deposit is characterized by potassic alteration forming K-feldspar after plagioclase in the inner core of the granodioritic intrusion, pyritic-phyllic and propylitic alterations in the outer part of the intrusion. Pyrite + quartz + white mica represent the pyritic-phyllic alteration, and chlorite + epidote + calcite + quartz the propylitic alteration. The latter alteration types overprint earlier potassic alteration.

\section{Analytical Procedures}

\subsection{Whole-Rock Chemical Composition}

After examining over 40 samples collected from the DBS-TS intrusions, we selected 12 representative samples (eight from the DBS intrusions, two samples of the country rock Tonshan Formation, and two from the Mesozoic monzonitic intrusions) for this study. The analyses were performed in the Yanduzhongshi Geological Analysis Laboratories Ltd., Beijing, China. Major elements for whole-rock samples were determined using a Shimadzu XRF-1800 X-ray fluorescence spectrometer. Powered samples, weighing approximately $1.2 \mathrm{~g}$ were fused with lithium tetraborate $\left(\mathrm{Li}_{2} \mathrm{~B}_{4} \mathrm{O}_{7}, 6 \mathrm{~g}\right)$ at $1050{ }^{\circ} \mathrm{C}$ for $20 \mathrm{~min}$. Duplicate analysis of Chinese national standard sample $\mathrm{GSR}_{3}$ shows that the precision is $1 \%$ for elements $>5 \mathrm{wt} . \%$, and $10 \%$ for elements $<5 \mathrm{wt} . \%$. Loss on ignition was measured as 
weight loss of the samples after $1 \mathrm{~h}$ baking at $1000^{\circ} \mathrm{C}$. Trace element concentrations were determined using a Perkin-Elmer Sciex ELAN 6000 inductively coupled plasma mass spectrometer (ICP-MS) after $\mathrm{HNO}_{3}+\mathrm{HF}$ digestion of about $40 \mathrm{mg}$ of sample powder in a Teflon vessel at $150{ }^{\circ} \mathrm{C}$. Analytical accuracy and precision were monitored by the Chinese national standard GSR 1 (granite) and $\mathrm{GSR}_{3}$ (basalt). The precision is better than $5 \%$ of the quoted values for elements present at $>1 \mathrm{ppm}$, and about $10 \%$ for elements less than $1 \mathrm{ppm}$. Accuracy is estimated to be better than $5 \%$ for the reported values.

\subsection{Zircon Trace-Element Analyses}

Twelve representative samples from the DBS-TS porphyry Cu-Mo deposits were selected to determine trace element contents in zircon. Zircon grains were separated using conventional magnetic and density techniques. Approximately 100 to 200 clear zircon grains were hand-picked under a binocular microscope, mounted in an Epoxy resin 1 inch in diameter, and polished to expose the centers of zircon grains for individual samples. Prior to analytical work, all zircon grains were examined under a transmitted light microscope as well as cathodoluminescence images using a scanning electron microscope (CL-SEM) at the University of Ottawa. Most grains are transparent euhedral crystals ranging in size from 50 to $100 \mathrm{~mm}$.

Zircon analyses were performed at the University of Ottawa with a Photon Machines Analyte G2 excimer laser ablation system attached to an Agilent 7700× ICP-MS with a second interface pump that approximately doubles instrument sensitivity. A spot size of $40 \mathrm{~mm}$ and $10 \mathrm{~Hz}$ laser repetition rate were employed. Element concentrations were obtained using count ratios of the elements to $\mathrm{Si}$ in zircon and those in NIST SRM612G [62] assuming stoichiometric concentration of $\mathrm{Si}$ in zircon grains. Data were processed using GLITTER [63]. Six to twelve representative zircon grains were selected from each of the 12 samples of this study. Since sector-zoned zircon grains commonly show a highly heterogeneous distributions of elements [64], CL images of grains were carefully examined to make sure no sector zoning was selected for analysis (Figure S1). Minute inclusions of REE-bearing minerals (e.g., apatite, titanite, and monazite) and faint cracks are common in zircon grains and the counts of $\mathrm{Ca}, \mathrm{Sr}, \mathrm{P}, \mathrm{Fe}$, and La were monitored during the analysis (Figure S1). Analytical data with spikes of these elements were discarded. The analytical method is essentially identical to that described by Kobylinski et al. [44].

Cerium anomalies, $\mathrm{Ce}^{4+} / \mathrm{Ce}^{3+}$, were calculated following the method proposed by Ballard et al. [31], where the abundance of $\mathrm{Ce}^{3+}$ is determined from the REEs and Y concentrations in zircon and whole-rock data on the basis of a lattice-strain model for mineral-melt partition of elements. The concentration of $\mathrm{Y}$ is included in the calculation because the geochemical properties of $Y$ are identical to those of Ho and because the $Y$ concentration is always higher than the latter. The accuracies of zircon trace elements are overall better than $10 \%$, except La and Pr, which are commonly up to $20 \%$.

\section{Results}

\subsection{Whole-Rock Geochemistry}

The DBS granodiorite-diorite contain $\mathrm{SiO}_{2}$ contents varying from 61.1 to $69.1 \mathrm{wt} . \%$ and moderate alkalis $\left(\mathrm{K}_{2} \mathrm{O}+\mathrm{Na}_{2} \mathrm{O}=5.98 \sim 7.10\right.$ wt. $\%$; Table S1), which plot in the fields of granodiorite and diorite in the diagram of $\mathrm{SiO}_{2}$ vs. $\left(\mathrm{K}_{2} \mathrm{O}+\mathrm{Na}_{2} \mathrm{O}\right)$ by Middlemost ([65] Figure 4a). This is consistent with the modal abundance of minerals as well as studies carried out by previous researchers (e.g., [13,24,26,28,66]). They are high in $\mathrm{Al}_{2} \mathrm{O}_{3}(12.4 \sim 16.7$ wt. \%; average $=15.6$ wt. \%), $\mathrm{CaO}\left(2.05 \sim 5.65\right.$ wt. \%; average = 2.89 wt.\%), and $\mathrm{Na}_{2} \mathrm{O}(3.05 \sim 6.27$ wt. \%; average $=3.53$ wt. $\%$ ), with $\mathrm{A} / \mathrm{NK}$ and $\mathrm{A} / \mathrm{CNK}$ in the range of 1.41 to 3.09 and $0.84 \sim 1.55$, respectively, which are in between metaluminous and paraluminous (Table S1). Mineralized granodiorites show relatively higher $\mathrm{K}_{2} \mathrm{O}\left(3.01 \sim 3.29\right.$ wt. $\%$ ) and $\mathrm{K}_{2} \mathrm{O} / \mathrm{Na}_{2} \mathrm{O}(0.94 \sim 6.62)$ than those variably altered samples (Table S1), and plot in the field of "high-K calc-alkali series" in the $\mathrm{K}_{2} \mathrm{O}$ vs. $\mathrm{SiO}_{2}$ diagram by Peccerillo and Taylor ([67] Figure 4b) due to alteration forming white mica and K-feldspar after plagioclase. Variably altered granodiorite and 
diorite plot mostly in the fields of calc-alkali series and high-K calc-alkali series in the $\mathrm{K}_{2} \mathrm{O}$ vs. $\mathrm{SiO}_{2}$ diagram (Figure $4 \mathrm{~b}$ ). DBS-7 is a slightly altered microgabbro which plots in the field of "calc-alkali series" in the $\mathrm{K}_{2} \mathrm{O}$ vs. $\mathrm{SiO}_{2}$ diagram (Figure $4 \mathrm{~b}$ ).

Overall, both mineralized granodiorites and variably altered granodiorites and diorites have high abundances of light REEs (LREEs) with $(\mathrm{La} / \mathrm{Yb})_{\mathrm{n}}$ of 7.11 11.4 and weak Eu negative anomalies $\left(\mathrm{Eu} / \mathrm{Eu}^{*}\right)$ of $0.81 \sim 0.97$ (Figure 5a). They show high contents of large ion lithophile elements (LILEs) and low high-field-strength elements (HFSEs) with marked positive $\mathrm{Pb}, \mathrm{Sr}$, and $\mathrm{Hf}$ anomalies and negative $\mathrm{Nb}, \mathrm{Ta}, \mathrm{Zr}$ and Ti anomalies with $\mathrm{Nb} / \mathrm{Ta}$ weight ratio varying from 8.9 to 16 in the extended trace elements plots (Figure 5b). Similar trace element patterns of all rocks from the DBS deposit suggest that they are likely cogenetic. Most samples contain low Y (<18 ppm) and $\mathrm{Yb}(<1.8 \mathrm{ppm})$, high Sr 290 750 ppm (average $=425 \mathrm{ppm}, \mathrm{n}=8)$ and high $\mathrm{Sr} / \mathrm{Y}$ ratios of 29 55 (average $=40, \mathrm{n}=8)($ Table S1), and plot in the adakitic field in the diagram of Sr/Y vs. Y (Figure 6) by Defant and Drummond [68]. Since igneous plagioclase is replaced by K-feldspar or white mica during the alteration, $\mathrm{Sr}$ content is likely lowered during the alteration. On the other hand, $\mathrm{Y}$ is not water soluble. Therefore, the ratios of $\mathrm{Sr} / \mathrm{Y}$ are likely to be the minimum values. Tongshan microgabbros (TNS1 and TNS3) contain low $\mathrm{SiO}_{2}$ contents (47.0 48.5 wt.\%) and moderate alkalis $\left(\mathrm{K}_{2} \mathrm{O}+\mathrm{Na}_{2} \mathrm{O}=5.12 \sim 5.51\right.$ wt.\%), which plot in the field of monzogabbro in the diagram for intrusive rocks of $\mathrm{SiO}_{2}$ vs. $\left(\mathrm{K}_{2} \mathrm{O}+\mathrm{Na}_{2} \mathrm{O}\right)$ by Middlemost ([65] Figure 4a). They show variable $\mathrm{K}_{2} \mathrm{O}$ contents $\left(0.17 \sim 3.29\right.$ wt. $\%$ ) and $\mathrm{K}_{2} \mathrm{O} / \mathrm{Na}_{2} \mathrm{O}$ ratios (0.03 1.48) and plot in the fields of "shoshonite series and low-K tholeiitic series" in the $\mathrm{K}_{2} \mathrm{O}$ vs. $\mathrm{SiO}_{2}$ diagram (Figure $4 \mathrm{~b}$ ). The high $\mathrm{K}_{2} \mathrm{O}$ content, $3.29 \mathrm{wt}$. $\%$, in sample TNS3 is due to potash alteration.
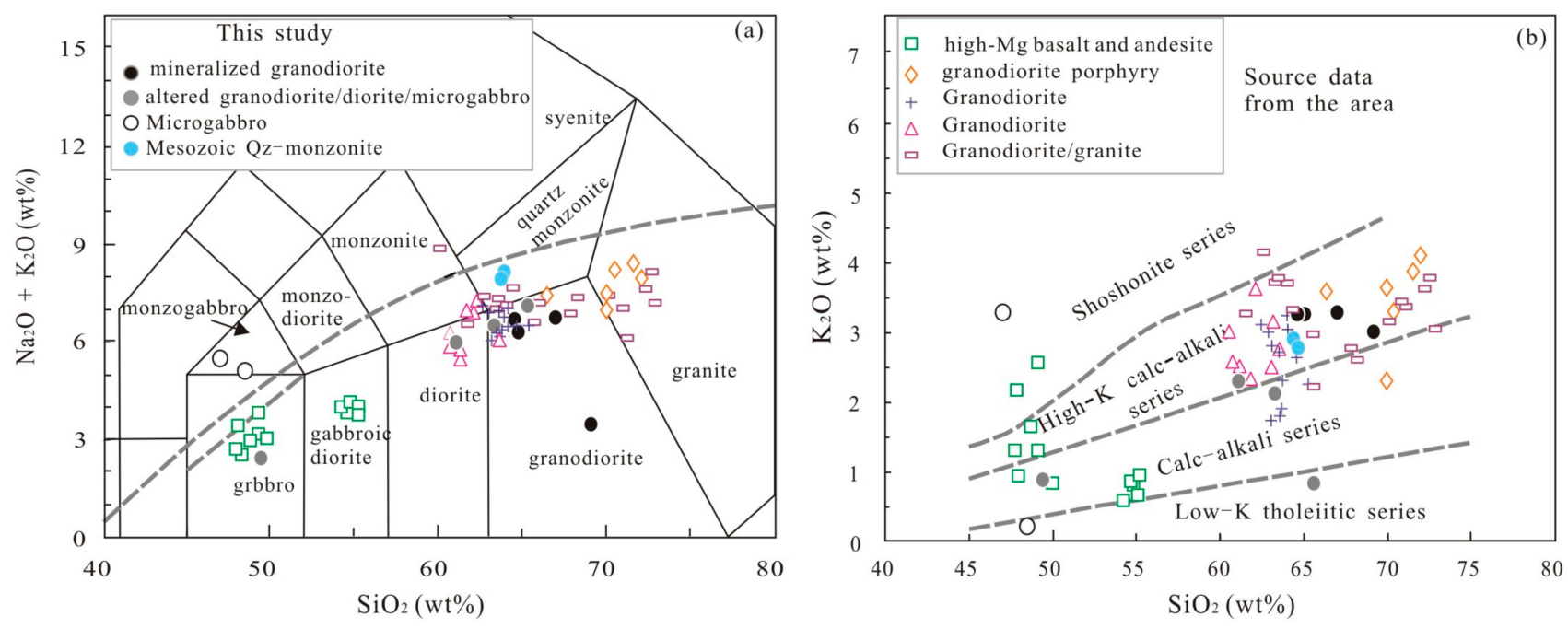

Figure 4. Plots of (a) $\mathrm{SiO}_{2}$ versus $\left(\mathrm{K}_{2} \mathrm{O}+\mathrm{Na}_{2} \mathrm{O}\right.$ ) (after [65]) and (b) $\mathrm{K}_{2} \mathrm{O}$ versus $\mathrm{SiO}_{2}$ (after [67]) for the early Paleozoic igneous rocks in the DBS-TS porphyry Cu-Mo deposit. Circles with different colors in Figure $4 \mathrm{~b}$ are the same as in (a). Data sources for (b): high-Mg basalt and andesite (green open square) from [26], granodiorite porphyry (brown diamond) from [24], granodiorite (blue cross) from [13], granodiorite (pink triangle) from [28], and granodiorite/granite (purple rectangle) from [66].

Compared to those DBS granodiorites or diorites, the TS microgabbro shows variable REE contents and low $(\mathrm{La} / \mathrm{Yb})_{\mathrm{n}}$ ratios (2.27 3.45) with no marked Eu anomalies (0.91 1.12) (Figure 5a). In addition, they show trace elemental patterns with marked positive $\mathrm{Pb}, \mathrm{Sr}$, and $\mathrm{Hf}$ anomalies and negative $\mathrm{Nb}, \mathrm{Ta}, \mathrm{Zr}$ and Ti anomalies with a Nb/Ta ratio of 14.0 to 19.8, similar to those DBS granodiorites and diorites (Figure 5b), suggesting that the TS microgabbros are likely co-genetic with those DBS intrusion. 

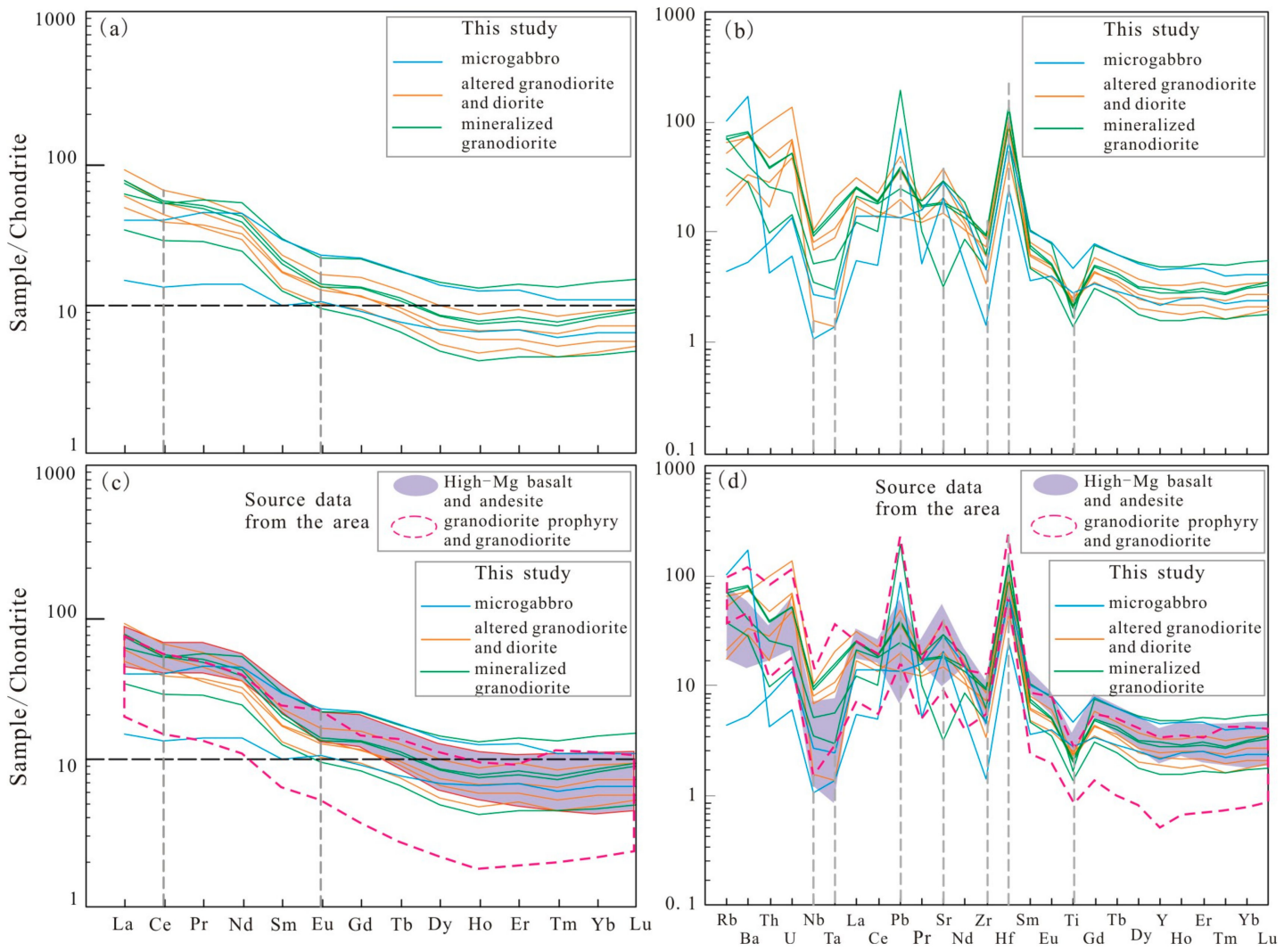

Figure 5. (a) Chondrite-normalized REE patterns and (b) primitive mantle-normalized trace element patterns for the early Paleozoic igneous rocks in the DBS-TS porphyry Cu-Mo deposit. (c) REE and (d) trace element patterns for igneous rocks in the DBS-TS porphyry Cu-Mo deposit in comparison with high Mg volcanic rocks and unaltered granodioritic rocks in the area. Note that the values of chondrite and primitive mantle are from [69], the data of high-Mg basalt and andesite are from [26], and the data of granodiorite porphyry and granodiorite are from [13,24,28].
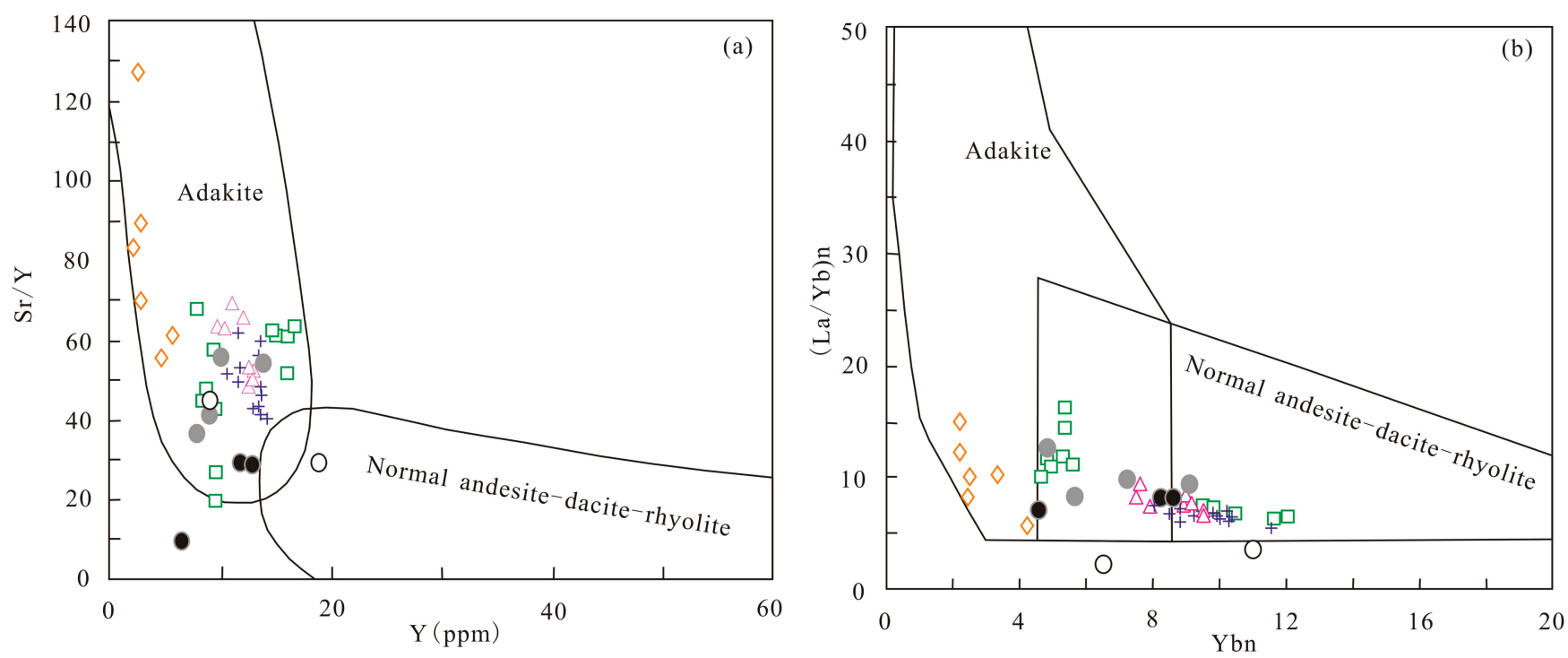

Figure 6. Plots of (a) Sr/Y versus $\mathrm{Y}$ and $(\mathbf{b})(\mathrm{La} / \mathrm{Yb})_{\mathrm{N}}$ versus $\mathrm{Yb}_{\mathrm{N}}$ early Paleozoic igneous rocks in the DBS-TS porphyry Cu-Mo deposit (after [68]). Symbols of the DBS-TS intrusions and the data sources for other rocks are the same as in Figure 4. 


\subsection{Zircon Geochemistry}

All zircon grains show sharp oscillatory zoning in CL-SEM images (Figure S1) due to varying Th and $U$ contents with high Th/U ratios ( $>0.34)$, confirming magmatic origin. All samples show low concentrations of LREEs and high amounts of HREEs, with pronounced positive Ce anomalies in the chondrite-normalized patterns (Figure S2a-d). The measured zircon trace element concentrations and values of $\mathrm{Ce}$ and $\mathrm{Eu}$ anomalies are listed in Table 1.

The values of zircon $\mathrm{Ce}^{4+} / \mathrm{Ce}^{3+}$ and $\mathrm{Ce} / \mathrm{Nd}$ in individual samples range from $231 \pm 111$ to $461 \pm 290$ and from $12.4 \pm 4.6$ to $20.3 \pm 8.6$ for the DBS mineralized and altered diorite and granodiotie, from $174 \pm 82$ to $357 \pm 177$ and from $7.4 \pm 3.6$ to $22 \pm 10$ for the DBS and TS microgabbros, and from $46 \pm 19$ to $63 \pm 39$ and from $5.0 \pm 1.4$ to $5.8 \pm 2.9$ for the early Mesozoic monzonites (Table 1). The values of zircon $\mathrm{Eu} / \mathrm{Eu}^{*}$ range from $0.56 \pm 0.03$ to $0.62 \pm 0.05$ for the DBS mineralized and altered diorite and granodiotie, from $0.33 \pm 0.27$ to $0.55 \pm 0.30$ for the DBS and TS microgabbros, and $0.75 \pm 0.06$ for the early Mesozoic monzonites (Table 1).

\subsection{Crystallization Temperatures of Zircon}

Zircon crystallization temperatures $\left(\mathrm{T}_{\mathrm{Ti}}{ }^{\circ} \mathrm{C}\right)$ for individual zircon grains are calculated using the Ti-in-zircon geothermometer of Ferry and Watson [70]. The calculation requires the activities of $\mathrm{TiO}_{2}\left(\alpha \mathrm{TiO}_{2}\right)$ and $\mathrm{SiO}_{2}$ in magmas. Activity of $\mathrm{SiO}_{2}$ is assumed to be 1 considering the abundant igneous quartz in all rocks. The activity of $\mathrm{TiO}_{2}$ should be $<1$ because there is no igneous rutile. Since all our samples contain primary titanite (Figure 3e,f), we use a value of 0.7 as $\alpha \mathrm{TiO}_{2}$, as suggested by Hayden and Watson [71] and Fu et al. [72].

The crystallization temperatures range from $719 \pm 25^{\circ} \mathrm{C}$ to $733 \pm 22^{\circ} \mathrm{C}$ for mineralized granodiorites, from $728 \pm 14{ }^{\circ} \mathrm{C}$ to $792 \pm 128{ }^{\circ} \mathrm{C}$ for altered microgabbro, diorite and granodiorite, and from $738 \pm 45^{\circ} \mathrm{C}$ to $794 \pm 61^{\circ} \mathrm{C}$ for the TS microgabbro (Table 2). The early Mesozoic monzonite shows high zircon crystallization temperatures ranging from $830 \pm 26{ }^{\circ} \mathrm{C}$ to $835 \pm 30{ }^{\circ} \mathrm{C}$ (Table 2).

Zircon saturation temperatures are also calculated using bulk rock compositions based on the equation of Watson and Harrison [73]. Except for microgabbro and one strongly mineralized sample (DBS 12), zircon saturation temperatures are comparable to $\mathrm{T}_{\mathrm{Ti}}{ }^{\circ} \mathrm{C}$ (Table 2), suggesting fairly quick crystallization of zircon.

\subsection{Magma Oxidation State}

Several methods have been proposed to calculate magma $\mathrm{fO}_{2}$ using zircon compositions (e.g., [74,75]). For our calculations, we used recently proposed methods by Smythe and Brenan [45,46] and Loucks et al. [47]. The method by Smythe and Brenan [46] uses the bulk-rock composition, zircon crystallization temperature and $\mathrm{Ce}^{3+} / \mathrm{Ce}^{4+}$ in zircon, water content in magma, and the ratios of non-bridging oxygen to tetrahedrally coordinated cations (NBO/T) of magmas [76]. In this study, we use the NBO/T ratios based on hydrous magmas and zircon crystallization temperatures based on Ti-in-zircon geothermometry. We chose to use the ratios of NBO/T in hydrous melt because the previous studies show that the hydrous-based ratios yield $f \mathrm{O}_{2}$ comparable to the results based on amphibole geothermobarometry [44]. The water content of magma is unknown. Water content in magma for porphyry $\mathrm{Cu}-(\mathrm{Au})$ deposits is in the range of $4 \sim 6 \mathrm{wt} . \%$ at $2 \mathrm{kbars}$ under FMQ +3 to +3.4 based on the published data (e.g., $>4$ wt. $\%$ by Garwin [77]; and 6 wt. $\%$ by Rohrlach and Loucks [78]). Kobylinski et al. [44] obtained the $\mathrm{H}_{2} \mathrm{O}$ content in the parental magmas for tonalite intrusions hosting the Gibraltar porphyry $\mathrm{Cu}$-Mo deposit to be $4.4 \pm 0.4 \mathrm{wt} . \%$ at a depth of $1.7 \mathrm{~km}$ based on amphibole composition. In this study, we assumed $\mathrm{H}_{2} \mathrm{O}$ content in the parental magma as 4 (lower limit), 5 (median of the published data) and $6 \mathrm{wt} . \%$ (upper limit) to calculate the $f \mathrm{O}_{2}$ of the DBS-TS deposit. 
Table 1. Major and trace element contents of zircon in samples from the DBS-TS ore-bearing intrusions.

\begin{tabular}{|c|c|c|c|c|c|c|c|c|c|c|c|c|c|c|c|c|c|c|}
\hline Lithology/Sample & $\begin{array}{c}\text { Element } \\
(\mathrm{ppm})\end{array}$ & $\mathbf{P}$ & $\mathrm{Ti}$ & $\mathrm{Sr}$ & $\mathbf{Y}$ & $\mathrm{Zr}$ & $\mathrm{Nb}$ & La & Ce & Pr & $\mathrm{Nd}$ & Sm & Eu & Gd & $\mathrm{Tb}$ & Dy & Но & Er \\
\hline \multicolumn{19}{|c|}{ Mineralized granodiorite } \\
\hline Sample DBS12 & mean & 134 & 5.65 & 0.45 & 587 & 460,915 & 2.30 & $<0.005$ & 12.0 & 0.05 & 0.94 & 1.80 & 0.83 & 9.61 & 3.32 & 43.5 & 18.3 & 97.7 \\
\hline$(\mathrm{n}=10)$ & sd & 20 & 0.91 & 0.08 & 204 & 14,661 & 0.65 & - & 7.74 & 0.02 & 0.43 & 0.81 & 0.27 & 4.49 & 1.43 & 16.7 & 6.4 & 31.0 \\
\hline Sample DBS16 & mean & 114 & 5.36 & 0.46 & 580 & 448,952 & 2.06 & $<0.005$ & 12.8 & 0.03 & 0.67 & 1.38 & 0.61 & 8.15 & 2.95 & 39.3 & 17.1 & 94.7 \\
\hline$(\mathrm{n}=10)$ & sd & 24 & 1.42 & 0.08 & 154 & 14,625 & 0.63 & - & 5.78 & 0.01 & 0.21 & 0.37 & 0.16 & 2.24 & 0.81 & 10.6 & 4.5 & 24.4 \\
\hline Sample DBSA4 & mean & 187 & 5.69 & 0.58 & 562 & 441,728 & 1.83 & $<0.005$ & 10.2 & 0.07 & 0.86 & 1.53 & 0.66 & 8.37 & 2.94 & 39.4 & 16.9 & 94.3 \\
\hline$(\mathrm{n}=11)$ & sd & 171 & 1.64 & 0.34 & 139 & 10,959 & 0.28 & - & 3.48 & 0.11 & 0.48 & 0.60 & 0.22 & 2.78 & 0.87 & 10.4 & 4.2 & 22.1 \\
\hline Sample DBSA5 & mean & 151 & 6.25 & 0.54 & 541 & 440,628 & 1.78 & $<0.005$ & 10.1 & 0.05 & 0.78 & 1.49 & 0.66 & 8.28 & 2.90 & 38.1 & 16.2 & 87.7 \\
\hline$(\mathrm{n}=11)$ & sd & 86 & 1.45 & 0.31 & 242 & 12,294 & 0.46 & - & 4.41 & 0.05 & 0.59 & 1.03 & 0.36 & 4.87 & 1.49 & 18.4 & 7.3 & 36.1 \\
\hline \multicolumn{19}{|c|}{ Altered granodiorite, diorite and microgabbro } \\
\hline Sample DBS1 & mean & 127 & 7.19 & 0.46 & 481 & 449,290 & 2.23 & $<0.005$ & 9.53 & 0.05 & 0.83 & 1.51 & 0.69 & 7.59 & 2.71 & 35.4 & 14.9 & 80.4 \\
\hline$(n=10)$ & sd & 18 & 1.34 & 0.06 & 105 & 225,77 & 0.42 & - & 2.53 & 0.02 & 0.25 & 0.39 & 0.16 & 1.73 & 0.58 & 7.6 & 3.3 & 17.7 \\
\hline Sample DBS8 & mean & 132 & 7.00 & 0.51 & 653 & 453,181 & 1.95 & $<0.005$ & 11.3 & 0.07 & 1.36 & 2.38 & 0.97 & 11.8 & 3.97 & 50.4 & 20.2 & 106 \\
\hline$(\mathrm{n}=12)$ & sd & 43 & 4.01 & 0.15 & 251 & 16,580 & 0.37 & - & 3.45 & 0.05 & 1.05 & 1.63 & 0.63 & 6.82 & 2.09 & 23.7 & 8.2 & 39 \\
\hline Sample DBS4 & mean & 108 & 5.83 & 0.45 & 500 & 444,044 & 2.76 & $<0.005$ & 12.0 & 0.04 & 0.75 & 1.47 & 0.62 & 7.72 & 2.73 & 36.3 & 15.3 & 82 \\
\hline$(\mathrm{n}=9)$ & sd & 17 & 0.93 & 0.07 & 98 & 12,771 & 0.63 & - & 4.82 & 0.03 & 0.42 & 0.59 & 0.22 & 2.33 & 0.70 & 8.4 & 3.2 & 16 \\
\hline Sample DBS7 & mean & 210 & 20.23 & 0.52 & 822 & 458,744 & 4.79 & $<0.005$ & 9.36 & 0.09 & 1.36 & 2.48 & 0.61 & 14.13 & 4.99 & 65.2 & 26.7 & 138 \\
\hline$(\mathrm{n}=7)$ & sd & 112 & 34.47 & 0.04 & 230 & 29,882 & 2.84 & - & 4.22 & 0.04 & 0.50 & 0.98 & 0.53 & 5.30 & 1.83 & 23.3 & 8.0 & 38.8 \\
\hline \multicolumn{19}{|c|}{ Microgabbros in Tongshan intrusion } \\
\hline Sample TNS-1 & mean & 291 & 12.82 & 0.57 & 667 & 426,553 & 2.89 & $<0.005$ & 10.5 & 0.12 & 1.88 & 2.95 & 0.53 & 13.3 & 4.58 & 57.4 & 22.2 & 109 \\
\hline Sample TNS-3 & mean & 198 & 7.0 & 0.97 & 580 & 394,203 & 2.41 & $<0.005$ & 17.8 & 0.04 & 0.86 & 1.94 & 0.80 & 11.03 & 3.76 & 45.213 & 17.6 & 86.9 \\
\hline$(\mathrm{n}=6)$ & sd & 162 & 3.2 & 1.33 & 111 & 19,866 & 0.45 & - & 7.62 & 0.01 & 0.26 & 0.61 & 0.38 & 3.25 & 1.18 & 13.741 & 4.5 & 17.2 \\
\hline \multicolumn{19}{|c|}{ Qz-monzonite } \\
\hline Sample DBSA1 & mean & 269 & 17.2 & 1.24 & 1329 & 428,056 & 1.46 & 0.056 & 22.2 & 0.29 & 4.78 & 7.78 & 3.93 & 33.8 & 10.5 & 122 & 45.0 & 213 \\
\hline$(\mathrm{n}=11)$ & sd & 48 & 5.0 & 0.84 & 323 & 25,059 & 0.22 & 0.034 & 5.61 & 0.15 & 2.05 & 2.65 & 1.09 & 8.96 & 2.61 & 29 & 10.9 & 51 \\
\hline Sample DBSA2 & mean & 289 & 16.4 & 1.01 & 1536 & 439,438 & 1.72 & 0.058 & 25.7 & 0.51 & 6.11 & 7.75 & 4.11 & 36.4 & 11.6 & 136 & 51.1 & 244 \\
\hline$(\mathrm{n}=11)$ & sd & 47 & 4.0 & 0.71 & 372 & 23,164 & 0.42 & 0.089 & 7.88 & 0.89 & 5.88 & 2.73 & 1.27 & 8.03 & 2.56 & 30 & 11.8 & 56 \\
\hline
\end{tabular}


Table 1. Cont.

\begin{tabular}{|c|c|c|c|c|c|c|c|c|c|c|c|c|c|c|c|c|c|}
\hline Lithology/Sample & $\begin{array}{c}\text { Element } \\
\text { (ppm) }\end{array}$ & $\mathrm{Tm}$ & $\mathbf{Y b}$ & Lu & Hf & Th & $\mathbf{U}$ & $\mathrm{Ce} / \mathrm{Nd}$ & $\left(\mathrm{Ce} / \mathrm{Ce}^{*}\right)^{\mathrm{a}}$ & $\left(\mathrm{Ce}^{4+} / \mathrm{Ce}^{3+}\right)^{\mathrm{b}}$ & $\left(E \mathbf{E} / \mathbf{E u}^{*}\right)^{\mathrm{c}}$ & $\mathrm{Hf} / \mathrm{Y}$ & $\mathrm{U} / \mathrm{Yb}$ & $\mathrm{Nb} / \mathrm{Yb}$ & $\mathrm{Gd} / \mathrm{Yb}$ & $\log (\mathrm{U} / \mathrm{Yb})$ & $\log (\mathrm{Nb} / \mathrm{Yb})$ \\
\hline \multicolumn{18}{|c|}{ Mineralized granodiorite } \\
\hline Sample DBS12 & mean & 25.1 & 290 & 62.5 & 9530 & 60.4 & 159 & 14.1 & 65.5 & 308 & 0.57 & 17.6 & 0.55 & 0.008 & 0.032 & -0.27 & -2.10 \\
\hline$(\mathrm{n}=10)$ & sd & 6.8 & 65 & 14.7 & 546 & 45.6 & 57 & 6.3 & 32.9 & 174 & 0.06 & 5.02 & 0.12 & 0.001 & 0.007 & 0.09 & 0.07 \\
\hline Sample DBS16 & mean & 24.2 & 284 & 62.5 & 9504 & 52.4 & 149 & 20.3 & 104 & 431 & 0.56 & 17.5 & 0.53 & 0.007 & 0.029 & -0.29 & -2.14 \\
\hline$(\mathrm{n}=10)$ & sd & 6.1 & 67 & 14.6 & 557 & 22.2 & 48 & 8.6 & 58 & 193 & 0.05 & 4.98 & 0.10 & 0.001 & 0.003 & 0.09 & 0.06 \\
\hline Sample DBSA4 & mean & 23.6 & 273 & 62.5 & 9323 & 46.1 & 132 & 14.7 & 70.9 & 307 & 0.56 & 17.7 & 0.49 & 0.007 & 0.030 & -0.32 & -2.17 \\
\hline$(\mathrm{n}=11)$ & sd & 5.1 & 54 & 12.3 & 560 & 18.9 & 32 & 7.3 & 42.8 & 185 & 0.03 & 5.61 & 0.11 & 0.001 & 0.005 & 0.09 & 0.07 \\
\hline Sample DBSA5 & mean & 21.9 & 254 & 55.6 & 8993 & 49 & 132 & 17.0 & 86.1 & 461 & 0.59 & 20.5 & 0.54 & 0.007 & 0.031 & -0.28 & -2.14 \\
\hline$(n=11)$ & sd & 8.3 & 88 & 18.8 & 718 & 26 & 44 & 9.2 & 64.2 & 290 & 0.05 & 11.5 & 0.12 & 0.002 & 0.009 & 0.09 & 0.10 \\
\hline \multicolumn{18}{|c|}{ Altered granodiorite, diorite and microgabbro } \\
\hline Sample DBS1 & mean & 21.5 & 261 & 51.6 & 8827 & 47.7 & 137 & 12.4 & 54.4 & 231 & 0.62 & 19.2 & 0.53 & 0.009 & 0.030 & -0.28 & -2.06 \\
\hline$(\mathrm{n}=10)$ & sd & 5.2 & 69 & 11.2 & 854 & 17.3 & 44 & 4.6 & 25.2 & 111 & 0.05 & 5.21 & 0.12 & 0.001 & 0.006 & 0.09 & 0.07 \\
\hline Sample DBS8 & mean & 26.1 & 295 & 61.7 & 9114 & 61 & 144 & 13.1 & 60.7 & 266 & 0.57 & 16.5 & 0.50 & 0.007 & 0.038 & -0.31 & -2.17 \\
\hline$(\mathrm{n}=12)$ & sd & 8.5 & 88 & 18.9 & 563 & 32 & 42 & 8.8 & 47.7 & 228 & 0.10 & 8.30 & 0.09 & 0.002 & 0.014 & 0.09 & 0.12 \\
\hline Sample DBS4 & mean & 20.9 & 244 & 53.1 & 9261 & 82 & 158 & 18.2 & 92.0 & 350 & 0.57 & 19.2 & 0.66 & 0.012 & 0.032 & -0.20 & -1.95 \\
\hline$(\mathrm{n}=9)$ & sd & 4.1 & 46 & 9.2 & 366 & 71 & 49 & 5.8 & 37.7 & 128 & 0.06 & 3.76 & 0.22 & 0.004 & 0.008 & 0.13 & 0.12 \\
\hline Sample DBS7 & mean & 32.2 & 340 & 67.6 & 10153 & 124 & 347 & 7.4 & 33.3 & 174 & 0.33 & 13.1 & 1.13 & 0.014 & 0.045 & -0.04 & -1.91 \\
\hline$(\mathrm{n}=7)$ & sd & 8.0 & 90 & 20.2 & 1323 & 91 & 190 & 3.6 & 24.9 & 82 & 0.27 & 3.30 & 0.92 & 0.007 & 0.021 & 0.30 & 0.27 \\
\hline \multicolumn{18}{|c|}{ Microgabbros in Tongshan intrusion } \\
\hline Sample TNS-1 & mean & 24.9 & 262 & 50.9 & 9690 & 143 & 358 & 7.4 & 28.5 & 197 & 0.37 & 16.4 & 1.37 & 0.012 & 0.051 & -0.16 & -2.06 \\
\hline \multirow{2}{*}{\multicolumn{18}{|c|}{ Qz-monzonite }} \\
\hline & & & & & & & & & & & & & & & & & \\
\hline Sample DBSA1 & mean & 47.6 & 489 & 87.0 & 6246 & 85 & 109 & 5.00 & 19.8 & 45.9 & 0.75 & 4.95 & 0.23 & 0.003 & 0.070 & -0.65 & -2.52 \\
\hline$(\mathrm{n}=11)$ & sd & 10.8 & 108 & 20.2 & 479 & 29 & 22 & 1.39 & 7.1 & 18.5 & 0.03 & 1.21 & 0.03 & 0.001 & 0.013 & 0.06 & 0.07 \\
\hline Sample DBSA2 & mean & 53.2 & 534 & 101 & 6487 & 93.1 & 125 & 5.76 & 23.5 & 62.6 & 0.75 & 4.41 & 0.23 & 0.003 & 0.068 & -0.64 & -2.50 \\
\hline$(\mathrm{n}=11)$ & sd & 11.2 & 97 & 23.3 & 540 & 28.8 & 33 & 2.85 & 15.7 & 38.8 & 0.06 & 0.87 & 0.04 & 0.000 & 0.010 & 0.06 & 0.06 \\
\hline
\end{tabular}

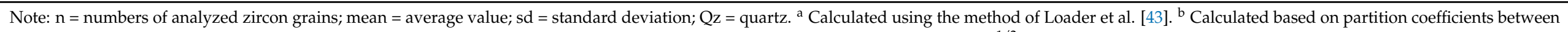

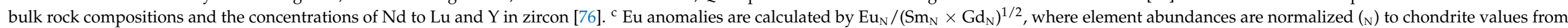
McDonough and Sun [69]. 
Table 2. Calculated average Ti-in-zircon temperature $\left({ }^{\circ} \mathrm{C}\right)$ and oxidation states $\left(\log f \mathrm{O}_{2}\right.$ and $\left.\Delta \mathrm{FMQ}\right)$ in individual samples from the Duobaoshan-Tongshan intrusions.

\begin{tabular}{|c|c|c|c|c|c|c|c|c|c|c|c|c|c|c|c|c|c|c|}
\hline \multirow{2}{*}{$\begin{array}{l}\text { Lithology/ } \\
\text { Sample }\end{array}$} & \multirow{2}{*}{$\begin{array}{l}\text { Numbers of } \\
\text { Analyzed } \\
\text { Zircon }\end{array}$} & \multirow{2}{*}{$\begin{array}{l}\mathrm{T}_{\mathrm{Ti}} \\
\left({ }^{\circ} \mathrm{C}\right)^{\mathrm{a}}\end{array}$} & \multirow{2}{*}{ Uncertainty } & \multirow{2}{*}{$\begin{array}{c}\text { T-Zircon } \\
\left({ }^{\circ} \mathrm{C}\right)^{\mathrm{b}}\end{array}$} & \multicolumn{4}{|c|}{5 wt. $\% \mathrm{H}_{2} \mathrm{O}^{c}$} & \multicolumn{4}{|c|}{$4 \mathrm{wt} . \% \mathrm{H}_{2} \mathrm{O}^{\mathrm{c}}$} & \multicolumn{4}{|c|}{6 wt. $\% \mathrm{H}_{2} \mathrm{O}^{\mathrm{c}}$} & \multirow{2}{*}{$\Delta \mathrm{FMQ}^{\mathrm{f}}$} & \multirow{2}{*}{ Sd } \\
\hline & & & & & $\log f \mathrm{O}_{2}{ }^{\mathrm{d}}$ & Error & $\Delta F M Q^{\mathrm{e}}$ & Error & $\log \mathrm{fO}_{2}{ }^{\mathrm{d}}$ & Error & $\Delta F M Q^{\mathrm{e}}$ & Error & $\log f \mathrm{O}_{2}{ }^{\mathrm{d}}$ & Error & $\Delta \mathrm{FMQ}^{\mathrm{e}}$ & Error & & \\
\hline \multicolumn{19}{|c|}{ Mineralized granodiorite } \\
\hline DBS12 & 10 & 725 & 15 & $\mathrm{n} / \mathrm{a}$ & -15.4 & 1.2 & 1.00 & 1.2 & -15.8 & 1.2 & 0.54 & 1.2 & -15.0 & 1.2 & 1.44 & 1.2 & 0.56 & 0.62 \\
\hline DBSA4 & 11 & 724 & 25 & 790 & -15.1 & 1.2 & 1.37 & 1.2 & -15.5 & 1.2 & 0.91 & 1.2 & -14.6 & 1.2 & 1.82 & 1.2 & 0.54 & 0.45 \\
\hline DBSA5 & 11 & 733 & 22 & 734 & -14.9 & 1.2 & 1.35 & 1.2 & -15.3 & 1.2 & 0.88 & 1.2 & -14.4 & 1.2 & 1.80 & 1.2 & 0.41 & 0.41 \\
\hline \multicolumn{19}{|c|}{ Altered granodiorite, diorite and microgabbro } \\
\hline DBS1 & 10 & 747 & 17 & 716 & -14.5 & 1.2 & 1.41 & 1.2 & -15.0 & 1.2 & 0.96 & 1.2 & -14.1 & 1.2 & 1.85 & 1.2 & 0.22 & 0.23 \\
\hline DBS8 & 12 & 737 & 46 & 752 & -14.4 & 1.2 & 1.54 & 1.2 & -14.9 & 1.2 & 1.09 & 1.2 & -14.0 & 1.2 & 1.97 & 1.2 & 0.54 & 0.52 \\
\hline DBS7 & 7 & 792 & 128 & $\mathrm{n} / \mathrm{a}$ & -11.6 & 1.4 & 4.19 & 1.4 & -12.1 & 1.4 & 3.75 & 1.4 & -11.2 & 1.4 & 4.61 & 1.4 & -0.94 & 1.89 \\
\hline \multicolumn{19}{|c|}{ Microgabbros in Tongshan intrusion } \\
\hline TNS1 & 5 & 794 & 61 & $\mathrm{n} / \mathrm{a}$ & -13.4 & 1.1 & 1.39 & 1.1 & -13.9 & 1.1 & 0.92 & 1.1 & -13.0 & 1.1 & 1.83 & 1.1 & -0.64 & 1.62 \\
\hline TNS3 & 6 & 738 & 45 & $\mathrm{n} / \mathrm{a}$ & -14.1 & 1.2 & 1.89 & 1.2 & -14.6 & 1.2 & 1.41 & 1.2 & -13.7 & 1.2 & 2.34 & 1.2 & 0.60 & 0.30 \\
\hline & \multicolumn{18}{|c|}{ Qz-monzonite } \\
\hline DBSA1 & 11 & 835 & 30 & 839 & -11.6 & 1.1 & 2.39 & 1.1 & -12.0 & 1.1 & 1.93 & 1.1 & -11.1 & 1.1 & 2.84 & 1.1 & 1.11 & 0.32 \\
\hline DBSA2 & 11 & 830 & 26 & 837 & -11.5 & 1.1 & 2.53 & 1.1 & -12.0 & 1.1 & 2.07 & 1.1 & -11.1 & 1.1 & 2.98 & 1.1 & 1.28 & 0.22 \\
\hline
\end{tabular}

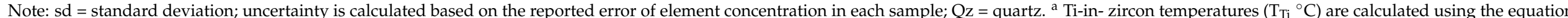

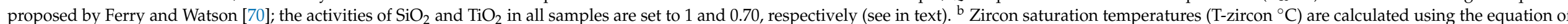

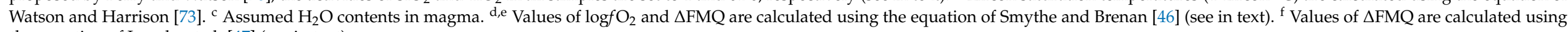
the equation of Loucks et al. [47] (see in text). 
We consider this assumed water content reasonable considering the solubility of water of a granitic melt is $4.26 \mathrm{wt} \%$ at $800{ }^{\circ} \mathrm{C} 1 \mathrm{kbar}$ [79]. Use of $5 \mathrm{wt} . \% \mathrm{H}_{2} \mathrm{O}$ yielded $f \mathrm{O}_{2}$ values (expressed as $\triangle F M Q$, logarithmic value from the fayalite-magnetite-quartz buffer) of FMQ +1.0 to +4.2 in individual samples. Using $6 \mathrm{wt}$. $\%$ or $4 \mathrm{wt} . \% \mathrm{H}_{2} \mathrm{O}$ produces a difference in $f \mathrm{O}_{2}$ less than 0.5 logarithmic units (Table 2). Propagation of error through the $f \mathrm{O}_{2}$ calculation, including the uncertainty of $\mathrm{Ce}^{3+} / \mathrm{Ce}^{4+}$ values, crystallization temperatures, analytical errors in the calculated $\mathrm{NBO} / \mathrm{T}$, and the estimated amount of water, suggests an estimated uncertainty of $<1.5 \mathrm{log}$ units (Table 2 ).

The $f \mathrm{O}_{2}$ values are similar among dioritic and granodioritic intrusions in DBS (FMQ $+1.0 \pm 1.2$ to FMQ $+2.4 \pm 1.3$ ) and the TS microgabbro samples (FMQ $+1.4 \pm 1.1$ to FMQ $+1.9 \pm 1.2$ ) except a microgabbroic dyke (Sample DBS7) that shows elevated $f \mathrm{O}_{2}$ value of FMQ +4.2 \pm 1.4 (Table 2). The Mesozoic Qz-monzonitic intrusions also show elevated oxidation state from FMQ $+2.4 \pm 1.1$ to FMQ $+2.5 \pm 1.1$ (Table 2).

The $\mathrm{fO}_{2}$ calculation based on the method of Loucks et al. [47] uses solely zircon chemistry without whole-rock compositions. The values range from FMQ -0.9 to FMQ +0.8 (averaging at FMQ +0.3) for individual samples in the DBS-TS deposit (Table 2), about 1 logarithmic unit systematically lower than those obtained based on the method of Smythe and Brenan [46]. The $\mathrm{fO}_{2}$ values are also calculated for other deposits elsewhere using the published zircon compositions from the deposits based on the equation of Loucks et al. [47], and the results are summarized in Table S2. The values obtained from the DBS-TS deposit are similar to those of central and western CAOB. Use of the method by Loucks et al. [47] and the method based on hydrous magmas of Smythe and Brenan [46] yielded comparable values for the Mesozoic Mo deposits in NE China (Table S2).

\section{Discussions}

6.1. Origin of the Ordovician Intrusions Hosting the DBS-TS Cu-Mo Deposit

6.1.1. Tectonic Setting Based on Zircon Trace Elements Geochemistry

Zircon grains in DBS-TS show high $\mathrm{U}$ and $\mathrm{U} / \mathrm{Yb}$, and low Ti and Hf (Table 1). They all fall into the field of continental arc in Figure 7. Especially, the zircons in DBS-TS plot above and close to the upper boundary of mantle-zircon array in Figure 8, suggesting that the parental magmas have continental arc affinity with a possible contribution of the mantle component. The trace elements of DBS-TS zircons show the evidence for fractional crystallization of hornblende, titanite and apatite (Figures 7c,d and 8).

The subduction related geochemical signatures for the DBS-TS intrusions (Figure 5), locations and ages of the Xinlin-Xiguitu and Hegenshan-Heihe sutures (Figure 1b [2,80,81]) suggest that the magmatism is related to the northwestward subduction of the Paleo-Asian Oceanic plate below the Erguna-Xing'an block at 482 to $476 \mathrm{Ma}$ (Figure S3a). Continuous subduction of the oceanic lithosphere finally led to the collision of the Songnen block with the Erguna-Xing'an amalgamated block at the early Carboniferous (Figure S3b). 

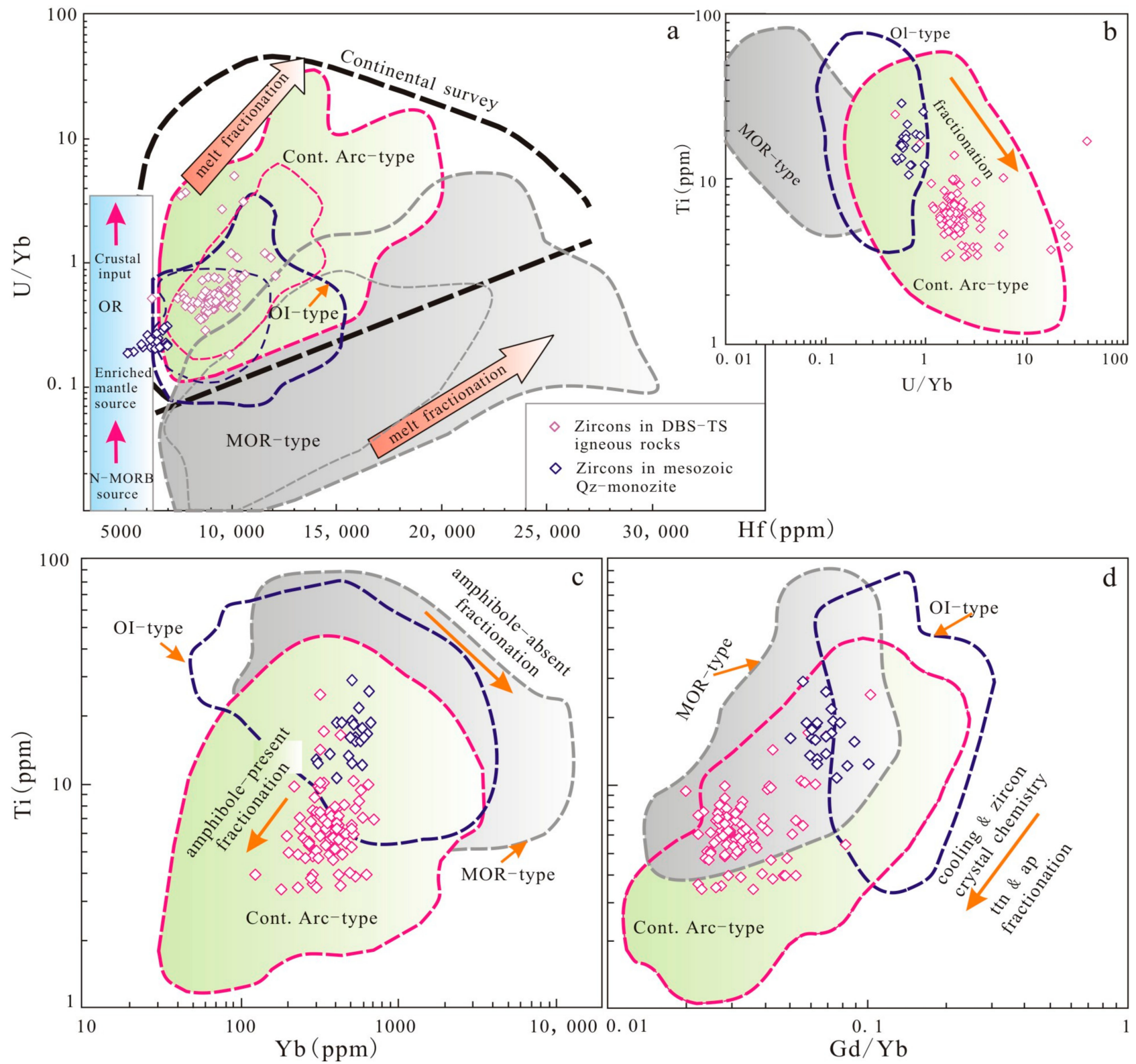

Figure 7. Discrimination diagrams based on trace elements of zircons (a) U/Yb versus Hf, (b) Ti versus U/Yb, (c) Ti versus $\mathrm{Yb}$, and (d) Ti versus Gd/Yb in zircon (after [82]). The field-labeled "Continental Survey" and lower bound (bold line) in (a) were defined by Grimes et al. [83]. The colored symbols in (b-d) are the same as in (a). The green, grey and white fields circled by pink, grey and blue dashed lines are fields of Cont. Arc-type, mid-oceanic ridge (MOR)-type and ocean island (OI)-type, respectively, based on the compiled dataset of [82]. The thin dashed lines (pink, grey and blue) in (a) refer to the boundary of $80 \%$ density distribution. (c) highlights contrasting trends formed by the arrays for MOR and continental arc zircon. (d) Highlights similar covariation in both MOR and arc zircon driven by the influence of cooling and possibly co-crystallization of phases in competition for REE with later-formed zircon. Effects of fractional crystallization of amphibole on the composition of zircon are illustrated in $(\mathbf{c}, \mathbf{d})$.

6.1.2. Origin of Magmas for the Ordovician Host Intrusions Based on Whole-Rock and Zircon Chemistries

Our dioritic and granodioritic samples show "adakite-like" geochemical signatures (Table S1; Figure 6). These signatures may be generated by several possible processes: (1) melting of subducted young oceanic lithosphere [68], (2) melting of delaminated ancient lower crust (e.g., [84]), (3) melting of thickened lower crust (e.g., [85-87]), and (4) fractional crystallization of water-rich arc magmas [44,88-91]. Adakites generated by the melting of 
subducted oceanic crusts are commonly characterized by high $\mathrm{Mg} \#=\mathrm{Mg} /(\mathrm{Mg}+$ total Fe $)$ values and high contents of $\mathrm{Cr}$ and $\mathrm{Ni}$ because they interact with mantle peridotites during their ascent (e.g., [68,92]). However, our diorites and granodiorites samples display relatively low values of $\mathrm{Mg \#} \mathrm{(0.37} \mathrm{0.53,} \mathrm{averaging} \mathrm{0.43)} \mathrm{and} \mathrm{low} \mathrm{contents} \mathrm{of} \mathrm{Cr}(10.1 \sim 22.2 \mathrm{ppm}$, averaging $14.9 \mathrm{ppm}$ ) and $\mathrm{Ni}$ (5.79 8.28 ppm, averaging $7.17 \mathrm{ppm}$ ) (Table S1). Therefore, possibility 1 is discounted. Considering that the DBS-TS intrusions formed in a continental arc, possibilities 2 and 3 are ruled out. This leaves possibility 4 , fractional crystallization of amphibole in water-rich magma, as the most likely cause for adakitic geochemical signature. This is consistent with the compositional trend of zircon (Figures 7 and 8) and also supported by the spoon-shaped REE patterns of bulk rock compositions because of high partition coefficients of middle REEs between amphibole and melt (e.g., [93-96]).

The rocks in this study are characterized by low initial compositions of ${ }^{87} \mathrm{Sr} /{ }^{86} \mathrm{Sr}$ $(=0.7038 \sim 0.7040$ for TS rocks, and $=0.7044 \sim 0.7045$ for DBS rocks), high values of $\varepsilon \mathrm{Nd}(\mathrm{t})$ $(=+3.5 \sim 5.4$ for TS rocks, and $=+8.1 \sim 8.7$ for DBS rocks $)$ and $\varepsilon \mathrm{Hf}(\mathrm{t})(=+9.0 \sim 14.3$ for TS rocks, and $+9.73 \sim 13.43$ for DBS rocks) as reported by Hu et al. [28] and Zhao et al. [24]. The isotope compositions suggest that the parental magmas were derived from a depleted mantle or juvenile lower crust/lithospheric mantle. The water-rich nature of the magmas and REE patterns of bulk rocks suggest that the source contained abundant amphibole.

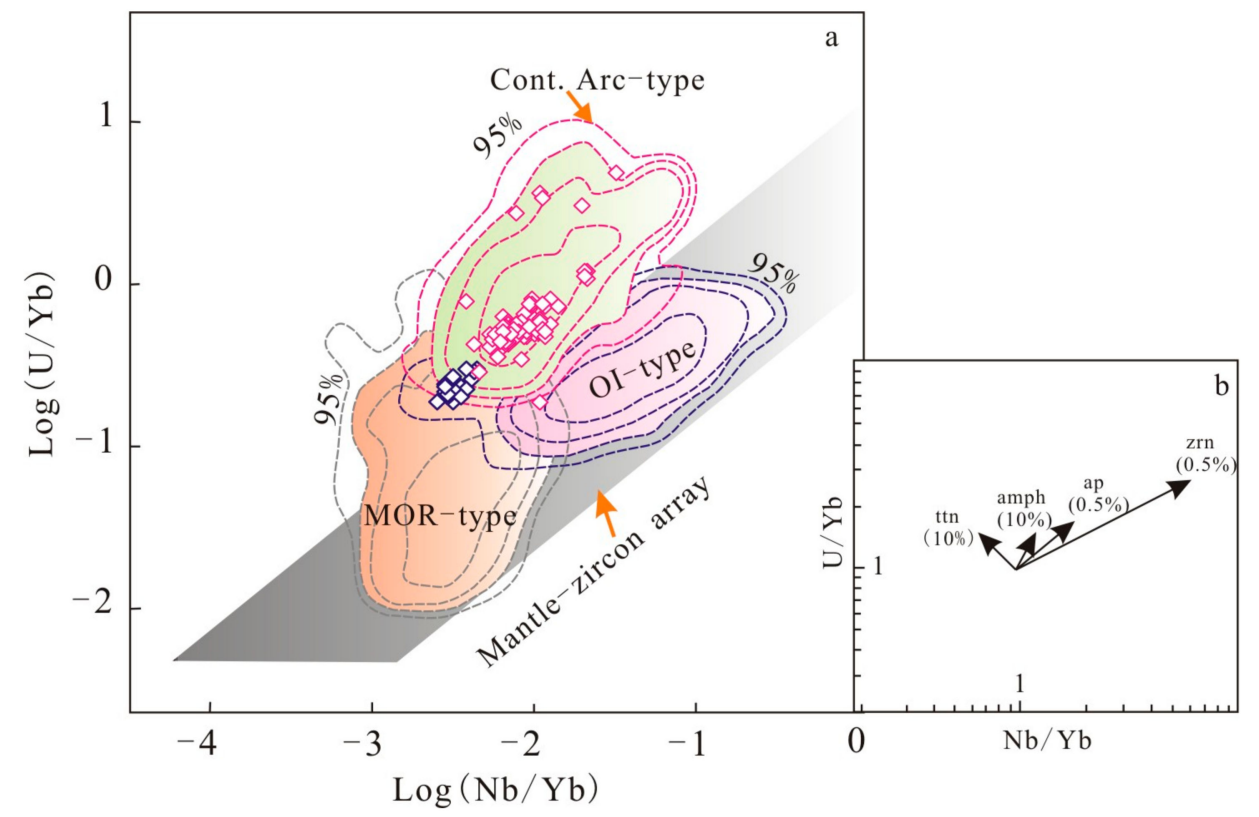

Figure 8. (a) Density distribution plots of zircon $\log (\mathrm{U} / \mathrm{Yb})$ versus $\log (\mathrm{Nb} / \mathrm{Yb})$ for discrimination of tectono-magmatic setting of the DBS-TS porphyry Cu-Mo deposit. Note: (1) The three shaded fields (green, pink and orange) are two-dimensional kernel density distributions for compiled datasets of mid-ocean ridge (MOR-type), plume-influenced settings of Iceland and Hawaii (ocean-island (OI)-type), and continental arc (Cont. arc-type) zircon by Grimes et al. [82]. The contours shown are for $50 \%, 80 \%, 90 \%$, and $95 \%$ levels, which represent the proportion of points inside the contour (after [82]). (2) All the zircons in the study area plot above the "Mantle- zircon array" and close to the upper bound. (3) Zircons in early Paleozoic DBS-TS deposit plot into the contour of 50\% Cont. Arc-type, and the zircons in early Mesozoic Qz-monzonite plot in the overlapping area toward MOR-type. (4) The colored symbols are the same as in Figure 7a. The inset (b) shows the effect of fractionation of select minerals on $\mathrm{U} / \mathrm{Yb}$ and $\mathrm{Nb} / \mathrm{Yb}$ ratios of the remaining melt (and later-formed zircons), relative to initial ratios $=1$. Vectors are shown to scale for the extent of fractional removal (of that mineral only) indicated by the percentages listed (after [82]). Ttn = titanite, amph = amphibole, ap = apatite, and zrn = zircon. 
6.2. Oxidation States of Parental Magmas for the DBS-TS Dioritic to Granodioritic Intrusions Based on Zircon Compositions

\subsubsection{Cerium Anomalies in Zircon}

(1) Controlling factors of zircon Ce anomalies

Cerium anomalies of zircon may be expressed as $\mathrm{Ce}^{4+} / \mathrm{Ce}^{3+}, \mathrm{Ce} / \mathrm{Ce}^{*}$ or $\mathrm{Ce} / \mathrm{Nd}$. Both $\mathrm{Ce} / \mathrm{Ce}^{*}[37,38,43]$ and $\mathrm{Ce} / \mathrm{Nd}[42]$ values are calculated solely based on zircon composition. These three parameters for zircons in the DBS-TS deposit show positive correlations (Figure S4a), which is consistent with the positive correlations reported from the Gibraltar deposit in Canada [44]. Compilation of published data of zircon trace elements confirms the positive correlations for the porphyry deposits in central and western CAOB (Figure S4b), the Mesozoic Mo deposits in NE China (Figure S4c,d), the Tintaya deposit in Peru (Figure S4e), the EI Teniente deposit in northern Chile (Figure S4f), the deposits in the Yulong belt in eastern Tibet (Figure S4g), and the Dexing deposit in SE China (Figure S4h).

The magnitude of $\mathrm{Ce}$ anomalies in zircon is affected by the fractionational crystallization of REE-rich minerals [43]. The ratio of Ce and Nd partition coefficients, $\mathrm{D}_{[\mathrm{Ce}]} / \mathrm{D}_{[\mathrm{Nd}]}$, in REE-rich phases (e.g., Ap, Ttn, $\mathrm{Hb}$ ) which co-crystallize with zircon is similar $\left(\mathrm{D}_{[\mathrm{Ce}]} / \mathrm{D}_{[\mathrm{Nd}]} \approx 1\right.$ for Ap [97]) or very low $\left(\mathrm{D}_{[\mathrm{Ce}]} / \mathrm{D}_{[\mathrm{Nd}]}=0.35\right.$ for Ttn and 0.33 for Hb [96]). Crystallization of these minerals causes the melt $\mathrm{Ce} / \mathrm{Nd}$ (and zircon $\mathrm{Ce} / \mathrm{Nd}$ ) to increase because of the removal of more $\mathrm{Nd}$ than $\mathrm{Ce}$. Ratio of $\mathrm{Ce}^{4+} / \mathrm{Ce}^{3+}$ in zircon is calculated using D values of REE between zircon and bulk rock [31]. If REE-rich mineral crystallizes, REEs including Ce contents decrease in the melt, leading to low estimates for $\mathrm{D}_{[\mathrm{Ce} 3+]}$ and high estimates for $\mathrm{Ce}^{4+} / \mathrm{Ce}^{3+}$. Therefore, the calculated $\mathrm{Ce}^{4+} / \mathrm{Ce}^{3+}$ ratios may vary considerably without any change in $\mathrm{fO}_{2}$.

(2) Zircon Ce anomalies and fertility of intrusions

The high value of $\mathrm{Ce}^{4+} / \mathrm{Ce}^{3+}$ in zircon is associated with fertile magmas associated with porphyry $\mathrm{Cu}$ deposits (e.g., $[16,18,31,32,44])$. However, $\mathrm{Ce}^{4+} / \mathrm{Ce}^{3+}$ ratios of zircon show large ranges in different deposits and metallogenic belts, and it is difficult to put an absolute $\mathrm{Ce}^{4+} / \mathrm{Ce}^{3+}$ value to separate fertile from infertile intrusions. The threshold of $\mathrm{Ce}^{4+} / \mathrm{Ce}^{3+}$ in zircons for ore-forming magmas is suggested to be 300 in the ChuquicamataEl Abra porphyry $\mathrm{Cu}$ belt in northern Chile by Ballard et al. [31]. This value is $>200$ for the Gibraltar porphyry Cu-Mo deposit, British Columbia of Canada [44], and >120 for the fertile ore-bearing hosting magmas for the porphyry $\mathrm{Cu}-\mathrm{Mo}-(\mathrm{Au})$ deposits in the central and western $\mathrm{CAOB}$ [16] and the porphyry $\mathrm{Cu}$ deposits in the Red River-Ailaoshan zone of eastern Tibet [32].

Elevated $\mathrm{Ce}^{4+} / \mathrm{Ce}^{3+}$ ratios are not always associated with fertile magmas, as pointed out by Viala et al. [98] in the Hualgayoc mining district in northern Peru. The TS microgabbro samples are barren and as wall rocks to the TS deposit, which show large range in $\mathrm{Ce}^{4+} / \mathrm{Ce}^{3+}$, from $197 \pm 154$ (TNS-1) to $357 \pm 177$ (TNS-3), and sample TNS-3 has similar $\mathrm{Ce}^{4+} / \mathrm{Ce}^{3+}$ values to DBS dioritic to granodioritic rocks (231 461; Table 1$)$. The size of the DBS-TS deposit is similar to those of the Bozshakol and Kounrad deposits in western CAOB (Table S2); however, the $\mathrm{Ce}^{4+} / \mathrm{Ce}^{3+}$ values in zircons of the DBS-TS samples are higher than that in the Bozshakol (250 270) and Kounrad (200 260) deposits. By contrast, values of $\mathrm{Ce}^{4+} / \mathrm{Ce}^{3+}$ in the DBS-TS deposit overlap most of the ranges of $\mathrm{Ce}^{4+} / \mathrm{Ce}^{3+}$ for those giant porphyry deposits, such as the Oyu Tolgoi, eastern CAOB (95-554; first quartile to third quartile with mean at 434; Figure 9b; Table S2), EI Teniente, northern Chile (75 588; first quartile to third quartile with mean at 432; Figure 9b; Table S2), and Yulong, eastern Tibet (171 515; first quartile to third quartile with mean at 354; Figure 9b; Table S2), but the size for the DBS-TS deposit is much smaller than these giant deposits. Even within the giant Oyu Tolgoi deposit, there is no significant distinction between zircons from Hugo Dummett ore body (high Cu grade and tonnage) and Heruga ore body (lower Cu grade and tonnage) considering that both systems are hosted by similar rocks and formed during the same magmatic epoch, i.e., under the same geodynamic conditions and probably derived 
from the same or similar magma source [43]. Thus, the different grade and/or size of these deposits are due to other factors, such as fluid chemistry, and/or fluid focusing [99]. Our data indicate that $\mathrm{Ce}^{4+} / \mathrm{Ce}^{3+}$ ratios should not be taken as an only parameter to separate fertile from infertile intrusions and would be unreliable if used to measure the size and/or grade of deposits.

Notwithstanding the problems associated with using Ce anomalies to evaluate the magma redox state, there still exists an empirical relationship between fertile porphyry systems and the compositions of zircons with higher average values for these parameters, as shown in Table S2. In particular, Ce/Nd can be obtained solely from zircon composition, and consequently, zircon may still be useful in exploration, although must be used with caution, and in cooperation with other conventional exploration techniques.
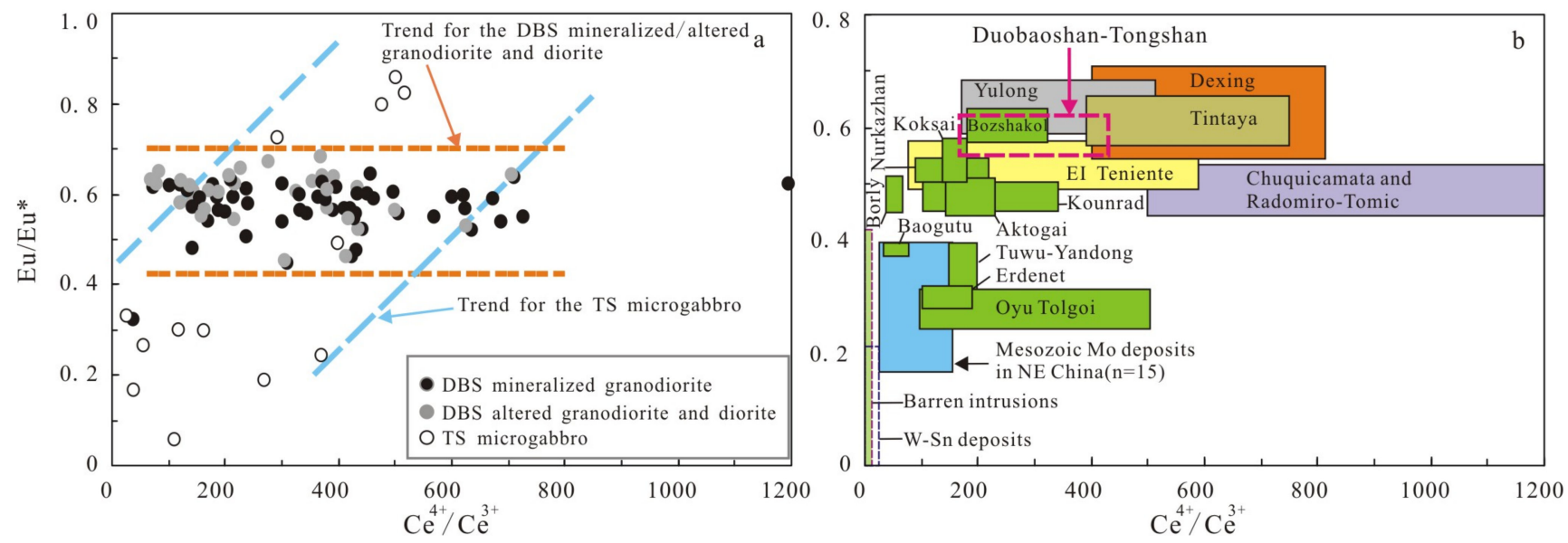

Figure 9. Plots of (a) $\mathrm{Eu} / \mathrm{Eu}^{*}$ versus $\mathrm{Ce}^{4+} / \mathrm{Ce}^{3+}$ for zircons in the gabbroic, dioritic and granodioritic intrusions of the DBS-TS porphyry Cu-Mo deposit, and (b) $\mathrm{Eu} / \mathrm{Eu}^{*}$ and $\mathrm{Ce}^{4+} / \mathrm{Ce}^{3+}$ for zircon from the DBS-TS deposit in comparison with the data from other porphyry $\mathrm{Cu}-\mathrm{Mo}-(\mathrm{Au})$ deposits in the world (lower and upper quartile values are shown as squares). Note: in (a), the altered and mineralized samples show variable $\mathrm{Ce}^{4+} / \mathrm{Ce}^{3+}$ values at relatively similar values of $\mathrm{Eu} / \mathrm{Eu}^{*}$, while zircons from microgabbro show $\alpha$ broad positive correlation between values of $\mathrm{Eu} / \mathrm{Eu}^{*}$ and $\mathrm{Ce}^{4+} / \mathrm{Ce}^{3+}$. In (b), data sources: the Baogutu, Bozshakol, Borly, Nurkazhan, Koksai, Aktogai, Kounrad and Erdenet deposits in the central and western CAOB [16], Oyu Tolgoi deposit in eastern CAOB [17,100], Tintaya deposit in Peru [42,101], Dexing deposit in SE China [102], Yulong deposit in eastern Tibet [103,104], EI Teniente deposit in Chile [105,106], Chuquicamata and Radomiro-Tomic deposit in Chile [31,105], Mesozoic Mo deposits in NE China [18], Sn-W deposit [107], and barren intrusions [108].

\section{(3) Zircon Ce anomalies and oxidation state of magma}

The ratio of $\mathrm{Ce}^{4+} / \mathrm{Ce}^{3+}$ in zircon has been considered to reflect the magmatic oxidation state; i.e., oxidized magma produces zircon with high $\mathrm{Ce}^{4+} / \mathrm{Ce}^{3+}$ ratios $[31,32]$, and reduced magma produces zircon with low $\mathrm{Ce}^{4+} / \mathrm{Ce}^{3+}$ values [107]. However, this is not the case for the DBS-TS deposit. Individual samples from the ore-bearing intrusions show a wide variation in zircon $\mathrm{Ce}^{4+} / \mathrm{Ce}^{3+}$ values $(174 \pm 82$ to $461 \pm 290$; average at 322; Table 1), but the calculated $f \mathrm{O}_{2}$ values show a rather narrow range, $\mathrm{FMQ}+1.0$ to +1.5 , for the mineralized samples and FMQ +1.4 to +4.2 for the variably altered samples (Table 2). Zircon grains from two samples from the Mesozoic Qz-monzonitic intrusion (barren) have much lower $\mathrm{Ce}^{4+} / \mathrm{Ce}^{3+}$ values $(45.9 \pm 18.5$ to $62.6 \pm 38.8)$ but yield higher $f \mathrm{O}_{2}$ values $(\mathrm{FMQ}+2.4$ to +2.5$)$. The lack of correlation between $\mathrm{Ce}^{4+} / \mathrm{Ce}^{3+}$ and oxidation conditions (Table 2; Figure 10a) suggests that zircon composition may not reflect the oxidation state of parental magmas.

To further examine the relationship between oxidation state and $\mathrm{Ce}^{4+} / \mathrm{Ce}^{3+}$, we recalculated the magma $f \mathrm{O}_{2}$ values of the ore-hosting intrusions for porphyry $\mathrm{Cu}-\mathrm{Mo}-(\mathrm{Au})$ deposits in the central and western CAOB (Table S3) using the method of Smythe and Brenan [46] and the bulk-rock and zircon compositions reported by Shen et al. [16] using 
the same assumption: 5 wt. $\% \mathrm{H}_{2} \mathrm{O}$ and 0.7 as $\mathrm{aTiO}_{2}$. These intrusions are low in $\mathrm{Ce}^{4+} / \mathrm{Ce}^{3+}$ ( $54 \pm 35$ to $468 \pm 427$; average 208 ; Table S3) and show comparable $f \mathrm{O}_{2}(\mathrm{FMQ}+1.1$ to +4.4 ; average 2.1; Table S3) values to the DBS dioritic to granodioritic intrusion (Tables 1 and 2). Even lower $\mathrm{Ce}^{4+} / \mathrm{Ce}^{3+}$ ratios (20 \pm 18 to $416 \pm 183$; average 137; Table S2) and comparable $\mathrm{fO}_{2}$ values (FMQ -1.3 to +4.3; average at FMQ +1.9; Table S2) are reported by Shu et al. [18] in intrusions hosting the 15 Mesozoic Mo deposits in NE China. As observed in the data from DBS-TS, no distinct correlation is observed between $\mathrm{Ce}^{4+} / \mathrm{Ce}^{3+}$ and $\mathrm{fO}_{2}$ (Figure 10a), but a broad positive correlation is observed between $\mathrm{fO}_{2}$ values and $\mathrm{T}\left({ }^{\circ} \mathrm{C}\right)$ (Figure $10 \mathrm{~b}$ ).

The results indicate that although porphyry $\mathrm{Cu}-(\mathrm{Mo})$ deposits show a large $\mathrm{Ce}^{4+} / \mathrm{Ce}^{3+}$ range in zircon from different metallogenic belts (or areas), they all yield a narrow range in $f \mathrm{O}_{2}$ from $\mathrm{FMQ}+1$ to +4 (Figure 10 ).
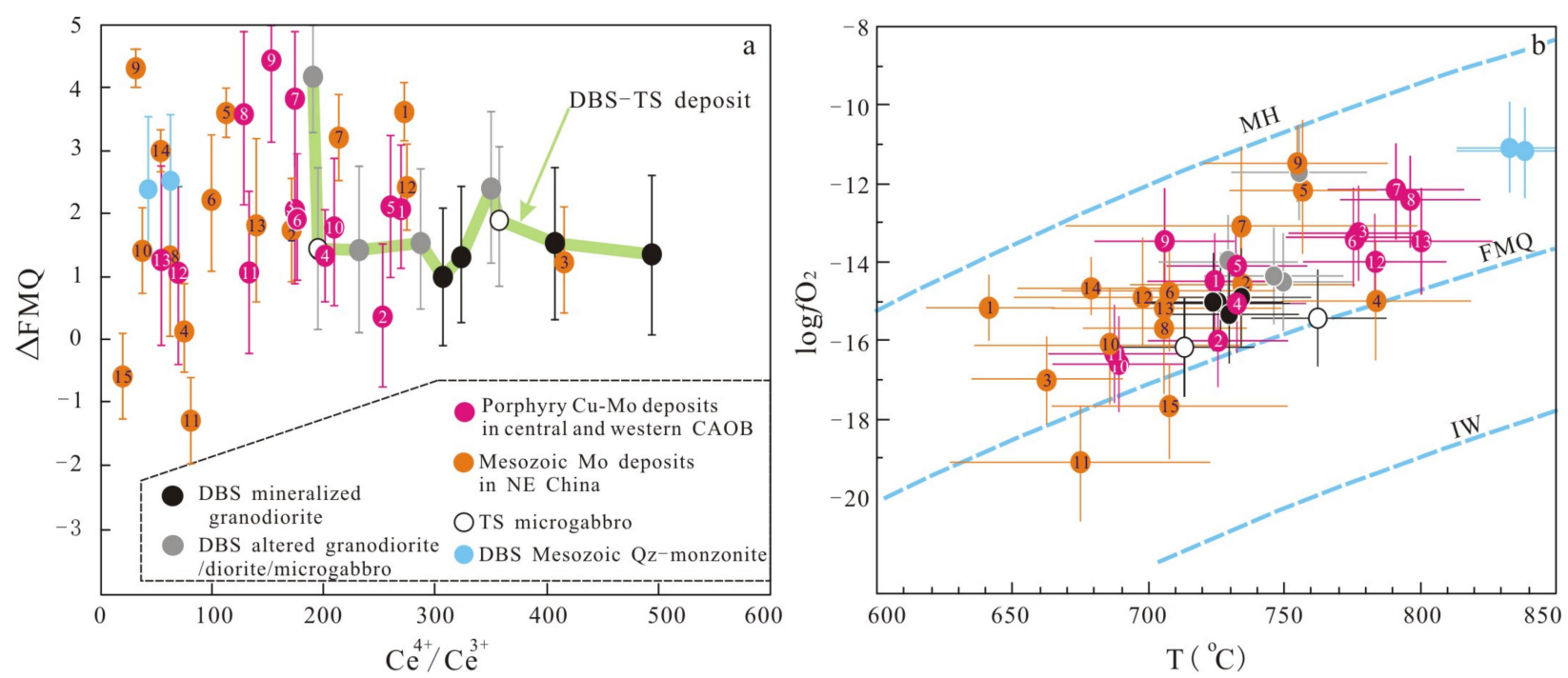

Figure 10. Plots of (a) $\triangle \mathrm{FMQ}$ versus $\mathrm{Ce}^{4+} / \mathrm{Ce}^{3+}$ and (b) $\log f \mathrm{O}_{2}$ versus $\mathrm{T}\left({ }^{\circ} \mathrm{C}\right)$ for individual samples from the DBS-TS porphyry Cu-Mo deposits. Black, grey, white and light blue circles in (b) are the same as in (a). Shown also for comparison includes 13 ore-bearing intrusions in central and western CAOB (pink solid circle with numbers: 1-2 = tonalite porphyry from Bozshakol, 3 = diorite from Nurkazghan, 4-5 = granodiorite porphyry and granodiorite from Kounrad, $6=$ tonalite porphyry from Aktogai, 7-8 = granodiorite from Erdenet, 9 = granodiorite porphyry from Koksai, 10-11 = tonalite porphyry from Tuwu-Yandong, 12 = granodiorite from Borly, and 13 = diorite from Baogutu; source data from [16]; values of log $f \mathrm{O}_{2}$ and $\mathrm{T}$ are recalculated in this study) and 15 Mesozoic Mo deposits in NE China (orange solid circle with numbers are the same as in Figure 1b; source data from [18]). MH and IW in Figure 10b are oxygen fugacity buffers for magnetite-hematite and iron-wustite, respectively.

\subsubsection{Europium Anomaly $\left(\mathrm{Eu} / \mathrm{Eu}^{*}\right)$ and Its Controlling Factors}

Europium anomalies may possibly reflect the oxidation state of magmas, given Eu is present as divalent cation in reduced magmas and trivalent cation in oxidized magmas. Since plagioclase preferentially incorporates $\mathrm{Eu}^{2+}$, crystallization of plagioclase depletes $\mathrm{Eu}$ in the melt, whereas crystallization of titanite results in a positive Eu anomaly [43].

The zircon grains in the DBS ore-bearing dioritic to granodioritic intrusion have relatively high $\mathrm{Eu} / \mathrm{Eu}^{*}$ ratios (from $0.56 \pm 0.03$ to $0.59 \pm 0.05$ for mineralized samples and from $0.57 \pm 0.06$ to $0.62 \pm 0.05$ for altered samples) (Table 1; Figures S2a,b and 9a), which appears to be consistent with the overall oxidized parental magmas. However, the zircon grains in the TS microgabbro samples have variable and lower $\mathrm{Eu} / \mathrm{Eu}^{*}$ ratios from $0.37 \pm 0.24$ to $0.55 \pm 0.30$ (Table 1; Figures S2c and 9a). Our data indicate that $\mathrm{Eu} / \mathrm{Eu}^{*}$ values do not correlate with $\mathrm{Ce}^{4+} / \mathrm{Ce}^{3+}$ in zircon (Table 1; Figure 9a) for the DBS dioritic and granodioritic samples, but weakly correlate with $\mathrm{Ce}^{4+} / \mathrm{Ce}^{3+}$ in zircon (Table 1 ; Figure 9a) for the TS microgabbro samples. The data suggest zircon Eu anomalies in the DBS dioritic and granodioritic samples are mainly controlled by factors unrelated to the redox conditions of magmas. Our data are consistent with the findings of previous 
workers (e.g., [43]), who suggested that Eu anomalies are primarily controlled by the crystallization of plagioclase and other phases, such as titanite, monazite and hornblende. Similar conclusions are drawn through studying ratios of other REEs and trace elements in zircons by some recent studies $[36,37,40]$. Thus, the relatively high and constant zircon $\mathrm{Eu} / \mathrm{Eu}^{*}$ values for the DBS mineralized and variably altered dioritic and granodioritic rocks suggest $\mathrm{H}_{2} \mathrm{O}$-rich parental magma suppressed early plagioclase crystallization, but promoted hornblende crystallization (e.g., $[44,49,109])$. The proposed interpretation is supported by the presence of plagioclase and variable hornblende throughout the DBS samples, and consistent with the high $\mathrm{Sr}($ average $=425 \mathrm{ppm})$ and $\mathrm{Sr} / \mathrm{Y}($ average $=40)$ in bulk rocks. On the contrary, the broad correlation of $\mathrm{Eu} / \mathrm{Eu}^{*}$ with $\mathrm{Ce}^{4+} / \mathrm{Ce}^{3+}$ and negative Eu anomalies in REE patterns for the TS microgabbro samples may suggest that minor fractional crystallization of plagioclase occurred prior to or during crystallization of zircon grains. The crystallization of plagioclase thus lowers $\mathrm{Eu} / \mathrm{Eu}^{*}$ in the residual melt. Large variation in $\mathrm{Ce}^{4+} / \mathrm{Ce}^{3+}$ in zircon associated by relatively constant $\mathrm{Eu} / \mathrm{Eu}^{*}$ is also observed in the Yulong porphyry $\mathrm{Cu}$ deposits in eastern Tibet, the Dexing deposit in SE China, the Tintaya deposit in Peru and EI Teniente deposit in Chile, and most of the porphyry $\mathrm{Cu}-\mathrm{Au}-(\mathrm{Mo})$ deposits in the central and western $\mathrm{CAOB}$ (Figure $9 \mathrm{~b}$ ). Thus, compared with $\mathrm{Ce}^{4+} / \mathrm{Ce}^{3+}$ or $\mathrm{Ce} / \mathrm{Nd}$, as a proxy of magma oxidation state, $\mathrm{Eu} / \mathrm{Eu}^{*}$ is not robust because it is strongly controlled by the crystallization of other minerals.

\subsubsection{Values of $f \mathrm{O}_{2}$ and Implications for Magma Source and Mineralization}

The mineral assemblage of magnetite, hornblende and titanite in the DBS-TS orebearing intrusions suggests that magma $f \mathrm{O}_{2}$ was above FMQ buffer [110]. Our newly obtained $f \mathrm{O}_{2}$ data (FMQ +1 to +4.2$)$ from the DBS porphyry deposit are consistent with the fact that arc magmas are commonly oxidized, FMQ +1 to +4 (e.g., [111-113]). The data are also consistent with our proposal that the DBS-TS ore-bearing intrusions were generated in a continental-arc during the subduction of the Paleo-Asian Ocean. It is well documented that metasomatized mantle wedges are more oxidized (e.g., [114-117]), and that magmas and the arc crust inherit their oxidized nature from the metasomatized mantle wedges $[111,112,115]$. The redox condition is a critically important factor for magma fertility [118-124]. An elevated oxygen fugacity will facilitate the extraction of $\mathrm{Cu}, \mathrm{Mo}$ and $\mathrm{Au}$ into the melt during partial melting because metal sulfides are incorporated into the melt owing to the much higher solubility of $\mathrm{S}$ as sulfate $\left(\mathrm{SO}_{4}{ }^{2-}\right)$ under oxidized conditions [125]. Copper, $\mathrm{Mo}$ and $\mathrm{Au}$ in an oxidized magma can then partition into a magmatic-hydrothermal fluid forming porphyry Cu-Mo deposits $[29,126,127]$. This explains why the igneous rocks associated with porphyry $\mathrm{Cu}-\mathrm{Mo}$ deposits of variable sizes (tonnage) have modestly high $f_{2}$ values in the CAOB, as well as in the NE China (Figure 10a,b).

Therefore, the magmatic oxidation state is an important indicator for forming porphyry deposits $[31,49,118,124]$, but may not be an accurate fertility indicator for porphyry deposits.

6.3. Comparison with Other Fertile Granitic Intrusions Hosting Porphyry Cu-Mo-(Au) Deposits in NE China and Elsewhere

Well-known metallogenic belts of porphyry $\mathrm{Cu}-\mathrm{Mo}-(\mathrm{Au})$ deposits are shown in Figures $1 \mathrm{~b}$ and 11 (porphyry Mo deposits in the Mesozoic metallogenic belt in NE China) and summarized in Table S2. 


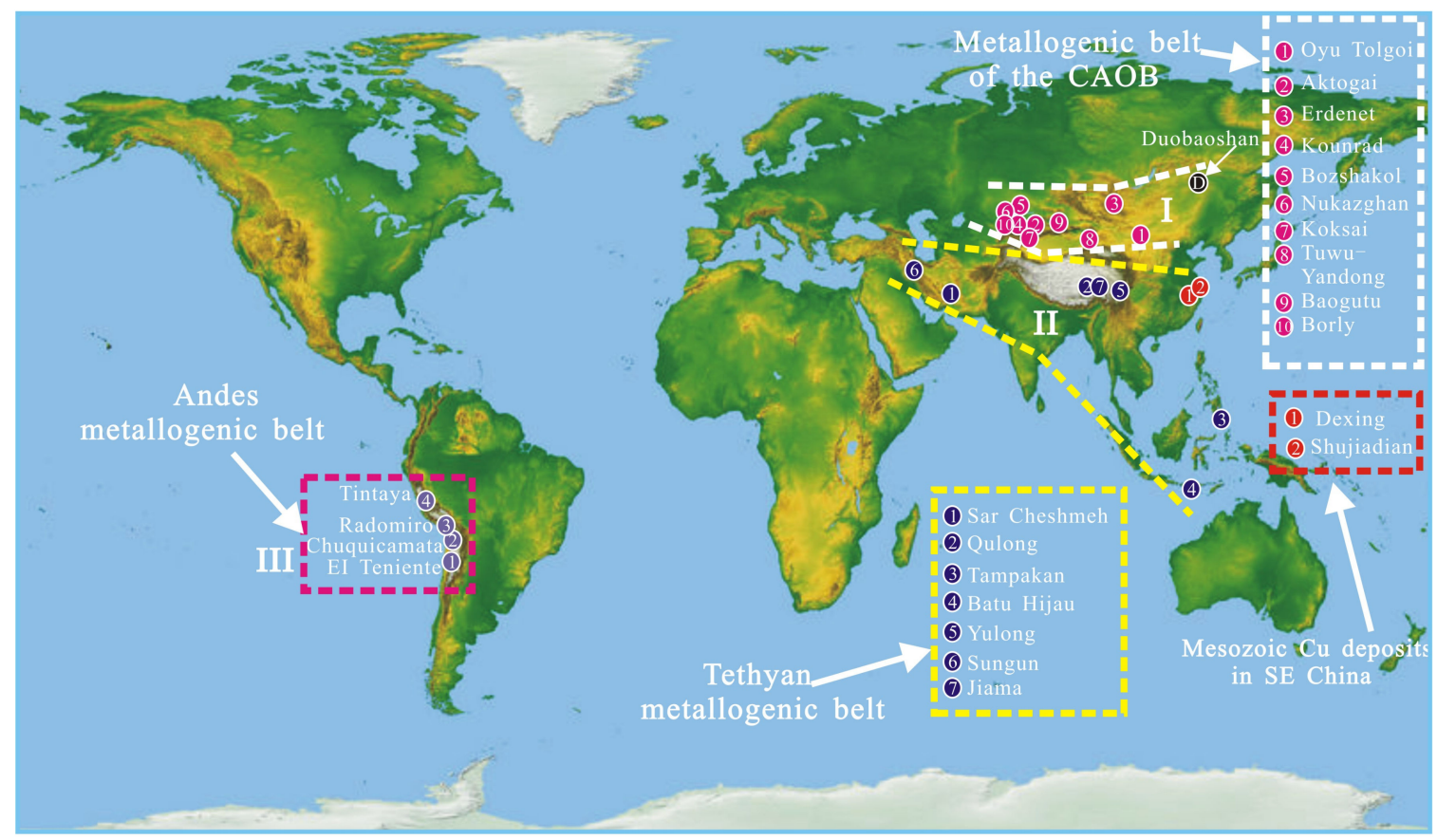

Figure 11. Distribution of the DBS-TS deposit and others in the well-known huge/large metallogenic belts of porphyry $\mathrm{Cu}-\mathrm{Mo}-(\mathrm{Au})$ deposits across the world. Note area I = metallogenic belt of CAOB; area II = Tethyan metallogenic belt; and area III = central Andes metallogenic belt. Mesozoic Mo metallogenic belt in NE China is shown in Figure 2b, not shown here.

\subsubsection{Tectonic Setting and Provenance for Magmatic Zircons}

Trace elements in zircon are useful in discriminating tectonic settings and provenances for the porphyry deposits in the well-known metallogenic belts across the world [82]. Compositions of magmatic zircons from the porphyry deposits in central and western CAOB and the Mesozoic Mo deposits in NE China (Figure S5a,b) fall into the contineral arc field, but Mo deposits show higher ratios of $U / Y b$, suggesting that their magma sources contain more crustal components. The porphyry deposits of the Tethys metallogenic belt according to their different geographical locations show a moderate content of $\mathrm{Hf}(5000 \sim 12,000 \mathrm{ppm})$ and different $\mathrm{U} / \mathrm{Yb}$ ratios (up to two orders of magnitude). For example, the porphyry deposits in western Tethys (e.g., Sar Cheshmch and Sungun) and central Tethys (e.g., Qulong, Jiama and Yulong) show similar U/Yb ratios (0.6 1.0) and Hf contents (6000 12,000 ppm), but the porphyry deposits in eastern Tethys (e.g., Tampakan and Batu Hijau) show rather low Hf contents $(6500 \sim 9500$ ppm) and U/Yb ratios $(<0.5)$, which fell into Cont. Arc-type and MOR-type fields, respectively (Figure S5a,b), suggesting the ongoing evolution of the Tethys belt through time and that the magmatic zircons in porphyry deposits of western and central Tethys are mainly from the continental arc and the zircons in deposits of eastern Tethys are mainly from mantle source. Compared with other metallogenic belts, magmatic zircons in porphyry deposits of the central Andes metallogenic belt show very large Hf difference (e.g., 2000 4000 ppm for EI Teniente [105,106], >9000 ppm for Tintaya [42,101] and 7000 15,000 ppm for EI Salvador [36]), although they all fall into the Cont. Arc-type field. In addition to the factors of magma sources, the Hf content in zircons is also affected by the fractional crystallization of magma. Hf contents increase during fractional crystallization.

\subsubsection{Cerium and $\mathrm{Eu}$ Anomalies $\left(\mathrm{Ce}^{4+} / \mathrm{Ce}^{3+}, \mathrm{Ce} / \mathrm{Nd}\right.$ and $\left.\mathrm{Eu} / \mathrm{Eu}^{*}\right)$ in Zircons}

The mean values of $\mathrm{Ce}$ anomalies, $\mathrm{Ce}^{4+} / \mathrm{Ce}^{3+}$ and $\mathrm{Ce} / \mathrm{Nd}$, for granitic intrusions hosting porphyry $\mathrm{Cu}-\mathrm{Mo}-(\mathrm{Au})$ deposits in these metallogenic belts are increasing in the order of: (1) Mesozoic porphyry Mo deposits belt NE China, (2) Porphyry Cu-Mo-(Au) deposits in the central and western CAOB, (3) Porphyry Cu-Mo deposits in the Tethys 
belt, and (4) Porphyry Cu-Mo deposits in the central Andes belt (Table S2). However, for $\mathrm{Eu} / \mathrm{Eu}^{*}$ values, the order is (1) the Mesozoic porphyry Mo deposit belt in NE China, (2) the porphyry $\mathrm{Cu}-\mathrm{Mo}-(\mathrm{Au})$ deposits in $\mathrm{CAOB}$, (3) Porphyry $\mathrm{Cu}$ deposits in the central Andes belt, and (4) Porphyry Cu-Mo deposits in the Tethys belt (Table S2).

There are weak correlations between $\mathrm{Ce}^{4+} / \mathrm{Ce}^{3+}$ (or Ce/Nd) and metal tonnage $(\mathrm{Cu}$ or $\mathrm{Mo})$ for the porphyry $\mathrm{Cu}-\mathrm{Mo}-(\mathrm{Au})$ deposits in Central and Western $\mathrm{CAOB}$, and for the Mesozoic porphyry Mo deposits in NE China. However, no distinct correlations are observed in the Tethys or central Andes metallogenic belts (Table S2).

\subsubsection{Oxidation State of Magmas}

In terms of oxidation state (calculated based on the model of Loucks et al. [39]), the Mesozoic Mo deposits in NE China are more oxidized with a mean value of FMQ +2.0, followed by the deposits in Tethys belt (FMQ +1.4), central Andes belt (FMQ +0.96), and the CAOB (FMQ +0.74), as shown in Table S2. However, no correlations are observed between values of $\mathrm{Ce}^{4+} / \mathrm{Ce}^{3+}$ and $\triangle \mathrm{FMQ}$ for deposits either in a single belt or among all the belts (Figure 12). The relatively oxidized nature of the Mesozoic granitic intrusions hosting porphyry Mo deposits in NE China is likely the result of the prolonged subduction of the oceanic plate from the Pacific Ocean below the eastern part of CAOB since the early Jurassic. The Mesozoic Qz-monzonites (e.g., sample DBSA1 and DBSA2) in the DBS-TS deposit also show an elevated oxidation state $(F M Q+1.2)$, supporting this interpretation.

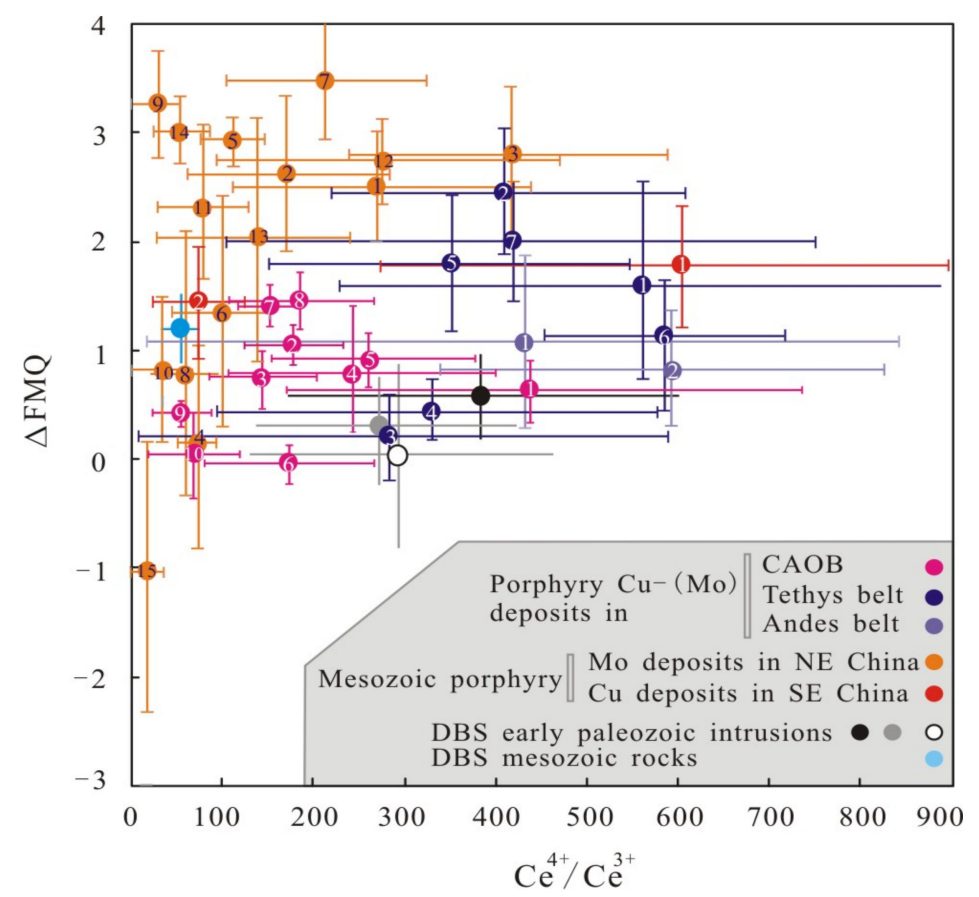

Figure 12. Plots of $\triangle \mathrm{FMQ}$ versus $\mathrm{Ce}^{4+} / \mathrm{Ce}^{3+}$ for intrusions host to the porphyry Cu-Mo deposits in well-known metallogenic belts. Note: (1) solid circles with numbers refer to porphyry Cu-Mo deposits, which are the same as listed in Table S2; (2). $\triangle F M Q$ values present in this figure are calculated by the method of Loucks et al. [47].

\section{Conclusions}

(1) The DBS-TS ore-bearing intrusions were formed from water-rich magmas. The hydrous magmas formed by partial melting of a juvenile lower crust/lithospheric mantle, or metasomatized mantle wedge in a continental-arc setting during northwestward subduction of the Paleo-Asian Oceanic plate below the Xing'an block.

(2) The dioritic and granodioritic intrusions show an adakitic signature of high $\mathrm{Sr} / \mathrm{Y}$ and low HREE, due to fractional crystallization of amphibole in water-rich magmas. 
(3) Ratios of $\mathrm{Ce}^{4+} / \mathrm{Ce}^{3+}$ and $\mathrm{Ce} / \mathrm{Nd}$ in zircons range from 174 to 461 (mean $322 \pm 203$ ) and from 7.4 to 20.3 (mean $14.9 \pm 7.8$ ) for samples from DBS-TS deposit, which confirms a positive correlation between the two parameters.

(4) The magma oxidation state is calculated to be FMQ $+1.0( \pm 1.2)$ to $+1.5( \pm 1.2)$ for mineralized samples and of FMQ $+1.4( \pm 1.2)$ to $+4.2( \pm 1.4)$ for variably altered samples using the hydrous-based equation by Smythe and Brenan [1]. The values are comparable to recalculated values using the same equation for fertile intrusions hosting the porphyry $\mathrm{Cu}-\mathrm{Mo}-(\mathrm{Au})$ deposits in the central and western $\mathrm{CAOB}$ and elsewhere.

(5) Although the magnitude of $\mathrm{Ce}$ anomalies in zircons is affected by the magmatic compositions and fractional crystallization of REE-rich minerals, positive anomalies of $\mathrm{Ce}$ are still associated with fertile porphyry systems. The values, however, may not be a valid fertility indicator of magmas.

Supplementary Materials: The following are available online at https://www.mdpi.com/article/10 $.3390 / \min 11050503$ / s1, Figure S1: SEM-cathodoluminescence images of zircon grains from the DBSTS ore-bearing microgabbroic, dioritic and granodioritic intrusions. Figure S2: Chondrite-normalized REE patterns of zircon for a (a) representative sample (DBS16) of mineralized granodiorites, (b) representative sample (DBS4) of altered granodiorites, (c) representative sample (DBS7) of microgabbros, and (d) representative sample (DBSA1) of Qz-monzonites. Figure S3: Evolution model for the Paleo-Asian Ocean and magmatism in NE China from (a) early Paleozoic to (b) early Carboniferous of the eastern CAOB (modified after [1,2]). Figure S4: (a) Plot of $\mathrm{Ce}^{4+} / \mathrm{Ce}^{3+}$ versus Ce/Nd for zircons in the gabbroic, dioritic and granodioritic intrusions of the DBS-TS porphyry Cu-Mo deposit. Shown also for comparison are (b) deposits in central and western CAOB [3], (c1 and c2) Mesozoic Mo deposits in NE China [4], (d) Yulong Cu deposit belt in eastern Tibet [5,6], (e) Dexing $\mathrm{Cu}$ deposit in SE China [7], (f) Tintaya Cu deposit in Peru [8,9], and (g) EI Teniente Cu deposit in Chile $[10,11]$. Figure S5: Tectono-magmatic setting discrimination diagrams of (a) U/Yb versus Hf, and (b) Ti versus U/Yb based on trace elements of zircons for porphyry deposits in the world-famous metallogenic belts. Note that the references are listed in Supplementary Figures. Table S1: Bulk-rock major and trace element contents of samples from the DBS-TS ore-bearing intrusions. Table S2: Summary of the porphyry $\mathrm{Cu}$-(Mo) deposits in other metallogenic belts (areas). Table S3. Average trace element contents of zircons and recalculated Ti-in zircon temperature $\left({ }^{\circ} \mathrm{C}\right)$ and $f \mathrm{O}_{2}$ values in porphyry $\mathrm{Cu}-\mathrm{Mo}-(\mathrm{Au})$ deposits from the central and western CAOB.

Author Contributions: Conceptualization, J.W. and K.H.; data curation, J.W.; laboratory analysis, K.H. and H.Y.; funding acquisition, J.W. and K.H.; investigation, Y.Y. and H.Y.; methodology, K.H.; resources, Y.Y.; writing — original draft, J.W.; writing—review \& editing, K.H. All authors have read and agreed to the published version of the manuscript.

Funding: This research was funded by the National Natural Science Foundation of China (NSFC), grant number 41472051, to J.W. and a Discovery grant from the Natural Science and Engineering Research Council of Canada (NSERC) to K.H.

Data Availability Statement: Not Applicable.

Acknowledgments: We are grateful to Samuel Morfin who helped with zircon trace element analysis at the University of Ottawa. Han Zhang is thanked for his assistance in analyzing whole rock major and trace elements at the Yanduzhongshi Geological Analysis Laboratories Ltd., Beijing, China. We thank the two anonymous journal reviewers for their constructive comments, which significantly improved the manuscript.

Conflicts of Interest: The authors declare no conflict of interest.

\section{References}

1. Wu, F.Y.; Jahn, B.M.; Wilde, S.; Sun, D.Y. Phanerozoic crustal growth: U-Pb and Sr-Nd isotopic evidence from the granites in northeastern China. Tectonophysics 2000, 328, 89-113. [CrossRef]

2. Wu, F.Y.; Sun, D.Y.; Li, H.M.; Jahn, B.M.; Wilde, S. A-type granites in northeastern China: Age and geochemical constraints on their petrogenesis. Chem. Geol. 2002, 187, 143-173. [CrossRef]

3. Chen, Y.J.; Zhang, C.; Li, N.; Yang, Y.F.; Deng, K. Geology of the Mo deposits in Northeast China. J. Jilin Univ. 2012, 42, 1223-1268. (In Chinese with English abstract) 
4. Bai, L.A.; Sun, J.G.; Gu, A.L.; Zhao, K.Q.; Sun, Q.L. A review of the genesis, geochronology, and geological significance of hydrothermal copper and associated metals deposits in the Great Xing'an Range, NE China. Ore Geol. Rev. 2014, 61, 192-203. [CrossRef]

5. Guo, F.; Fan, W.M.; Wang, Y.J.; Lin, G. Petrogenesis of the late Mesozoic bimodal volcanic rocks in the Southern Da Hinggan Mts, China. Acta Petrol. Sin. 2001, 17, 161-168. (In Chinese with English abstract)

6. Fan, W.M.; Guo, F.; Wang, Y.J.; Lin, G. Late Mesozoic calc-alkaline volcanism of post-orogenic extension in the northern Da Hinggan mountains, Northeastern China. J. Volcanol. Geotherm. Res. 2003, 121, 115-135. [CrossRef]

7. Meng, Q.R. What drove late Mesozoic extension of the northern China-Mongolia tract? Tectonophysics 2003, 69, 155-174. [CrossRef]

8. Hao, Y.J.; Ren, Y.S.; Duan, M.X.; Zhao, H.L.; Tong, K.Y.; Sun, Z.M. Tectonic setting of Triassic magmatic and metallogenic event in the Duobaoshan mineralization area of Heilongjiang Province, NE China. Geol. J. 2017, 52, 67-91. [CrossRef]

9. Deng, K.; Li, Q.G.; Chen, Y.J.; Zhang, C.; Zhu, X.F.; Xu, Q.W. Geochronology, geochemistry and Sr-Nd-Pb-Hf isotopes of the early Jurassic granodiorite from the Sankuanggou intrusion, Heilongjiang Province, Northeastern China: Petrogenesis and geodynamic implications. Lithos 2018, 296-299, 113-128. [CrossRef]

10. Hilde, T.W.C.; Uyeda, S.; Kroenke, L. Evolution of the western Pacific and its margin. Tectonophysics 1977, 38, 145-165. [CrossRef]

11. Hao, Y.J.; Ren, Y.S.; Duan, M.X.; Tong, K.Y.; Chen, C.; Yang, Q.; Li, C. Metallogenic events and tectonic setting of the Duobaoshan ore field in Heilongjiang province, NE China. J. Asian Earth Sci. 2015, 97, 442-458. [CrossRef]

12. Ge, W.C.; Wu, F.Y.; Zhou, C.Y.; Zhang, J.H. Porphyry Cu-Mo deposits in the eastern Xing'an-Mongolian Orogenic belt: Mineralization ages and their geodynamic implications. Chin. Sci. Bull. 2007, 52, 3416-3427. [CrossRef]

13. Wu, G.; Chen, Y.C.; Sun, F.Y.; Liu, J.; Wang, G.R.; Xu, B. Geochronology, geochemistry, and Sr-Nd-Hf isotopes of the early Paleozoic igneous rocks in the Duobaoshan area, NE China, and their geological significance. J. Asian Earth Sci. 2015, 97, 229-250. [CrossRef]

14. Jahn, B.M. The central Asian orogenic belt and growth of the continental crust in the Phanerozoic. Geol. Soc. Lond. Spec. Publ. 2004, 226, 73-100. [CrossRef]

15. Liu, Y.J.; Li, W.M.; Feng, Z.Q.; Wen, Q.B.; Neubauer, F.; Liang, C.Y. A review of the Paleozoic tectonics in the eastern part of Central Asian Orogenic belt. Gondwana Res. 2017, 43, 123-148. [CrossRef]

16. Shen, P.; Hattori, K.; Pan, H.D.; Jackson, S.; Seitmmuratova, E. Oxidation condition and metal fertility of granitic magmas: Zircon trace-element data from porphyry Cu deposits in the Central Asian Orogenic belt. Econ. Geol. 2015, 110, 1861-1878. [CrossRef]

17. Porter, T.M. The geology, structure and mineralisation of the Oyu Tolgoi porphyry copper-gold-molybdenum deposits, Mongolia: A review. Geosci. Front. 2016, 7, 375-407. [CrossRef]

18. Shu, Q.H.; Chang, Z.S.; Lai, Y.; Hu, X.L.; Wu, H.Y.; Zhang, Y.; Wang, P.; Zhai, D.G.; Zhang, C. Zircon trace elements and magma fertility: Insights from porphyry (-skarn) Mo deposits in NE China. Miner. Depos. 2019, 54, 645-656. [CrossRef]

19. Yin, B.C.; Ran, Q.C. The tectonic environments of metallogenesis of Duobaoshan super large copper deposit. Acta Mineral. Sin. 1997, 17, 220-224. (In Chinese with English abstract)

20. Wei, R.; Xu, J.H.; Zeng, Q.D.; Wang, Y.H.; Liu, J.M.; Chu, S.X. Fluid evolution of alteration and mineralization at the Duobaoshan porphyry $\mathrm{Cu}(\mathrm{Mo})$ deposit, Heilondiang province. Acta Petrol. Sin. 2011, 27, 1361-1374. (In Chinese with English abstract)

21. Liu, J.; Wu, G.; Li, Y.; Zhu, M.T.; Zhong, W. Re-Os sulfide (chalcopyrite, pyrite and molybdenite) systematics and fluid inclusion study of the Duobaoshan porphyry Cu (Mo) deposit, Heilongjiang Province, China. J. Asian Earth Sci. 2012, 49, 300-312. [CrossRef]

22. Xiang, A.P.; Yang, Y.C.; Li, G.T.; She, H.Q.; Guan, J.D.; Li, J.W.; Guo, Z.J. Diagenetic and metallogenic ages of Duobaoshan porphyry Cu-Mo deposit in Heilongjiang province. Kuangchuang Dizhi 2012, 31, 1237-1248. (In Chinese with English abstract)

23. Zeng, Q.D.; Liu, J.M.; Chu, S.X.; Wang, Y.B.; Sun, Y.; Duan, X.X.; Zhou, L.L.; Qu, W.J. Re-Os and U-Pb geochronology of the Duobaoshan porphyry Cu-Mo-(Au) deposit, Northeast China, and its geological significance. J. Asian Earth Sci. 2014, 79, 895-909. [CrossRef]

24. Zhao, C.; Qin, K.Z.; Song, G.X.; Li, G.M.; Li, Z.Z. Petrogenesis and tectonic setting of ore-related porphyry in the Duobaoshan Cu deposit within the eastern Central Asian Orogenic belt, Heilongjiang Province, NE China. J. Asian Earth Sci. 2018, 165, 352-370. [CrossRef]

25. Zhao, C.; Qin, K.Z.; Song, G.X.; Li, G.M. Switch of geodynamic setting from the Paleo-Asian ocean to the Mongol-Okhotsk ocean: Evidence from granitoids in the Duobaoshan ore field, Heilongjiang province, Northeast China. Lithos 2019, 336-337, 202-220. [CrossRef]

26. Zhao, C.; Qin, K.Z.; Song, G.X.; Li, G.M.; Li, Z.Z. Early Paleozoic high-Mg basalt-andesite suite in the Duobaoshan porphyry Cu deposit, NE China: Constraints on petrogenesis, mineralization, and tectonic setting. Gondwana Res. 2019, 71, 91-116. [CrossRef]

27. Wu, G.; Liu, J.; Zhong, W.; Zhu, M.T.; Mei, M.; Wan, Q. Fluid inclusion study of the Tongshan porphyry copper deposit, Heilongjiang province, China. Acta Petrol. Sin. 2009, 25, 2995-3006. (In Chinese with English abstract)

28. Hu, X.L.; Yao, S.Z.; Ding, M.C. Early Paleozoic magmatism and metallogeny in Northeast China: A record from the Tongshan porphyry Cu deposit. Miner. Depos. 2017, 52, 85-103. [CrossRef]

29. Hattori, K. High-sulfur magma, a product of fluid discharge from underlying mafic magma: Evidence from mount Pinatubo, Philippines. Geology 1993, 21, 1083-1086. [CrossRef]

30. Sillitoe, R.H. Porphyry copper systems. Econ. Geol. 2010, 105, 3-41. [CrossRef] 
31. Ballard, J.R.; Palin, J.M.; Campbell, I.H. Relative oxidation states of magmas inferred from Ce(IV)/Ce(III) in zircon: Application to porphyry copper deposits of northern Chile. Contrib. Mineral. Petrol. 2002, 144, 347-364. [CrossRef]

32. Liang, H.Y.; Campbell, I.H.; Allen, C.; Sun, W.D.; Liu, C.Q.; Yu, H.X.; Xie, Y.W.; Zhang, Y.Q. Zircon Ce $\mathrm{Ce}^{4+} / \mathrm{Ce}^{3+} \mathrm{ratios}$ and ages for Yulong ore-bearing porphyries in eastern Tibet. Miner. Depos. 2006, 41, 152-159. [CrossRef]

33. Zou, X.; Qin, K.; Han, X.; Li, G.; Evans, N.J.; Li, Z.; Yang, W. Insight into zircon REE oxy-barometers: A lattice strain model perspective. Earth Planet. Sci. Lett. 2019, 506, 87-96. [CrossRef]

34. Buret, Y.; von Quadt, A.; Heinrich, C.; Selby, D.; Waille, M.; Petcheva, I. From a long-lived upper-crustal magma chamber to rapid porphyry copper emplacement: Reading the geochemistry of zircon crystals at Bajo de la Alumbrera (NW Argentina). Earth Planet. Sci. Lett. 2016, 450, 120-131. [CrossRef]

35. Buret, Y.; Wotzlaw, J.F.; Roozen, S.; Guillong, M.; von Quadt, A.; Heinrich, C.A. Zircon petrochonological evidence for a plutonic-volcanic connection in porphyry copper deposits. Geology 2017, 45, 623-626. [CrossRef]

36. Lee, R.G.; Dilles, J.H.; Tosdal, R.M.; Wooden, J.L.; Mazdab, F.K. Magmatic evolution of granodiorite intrusions at the El Salvador porphyry copper deposit, Chile, based on trace element composition and U/Pb age of zircons. Econ. Geol. 2017, 112, 245-273. [CrossRef]

37. Lee, R.G.; Bryne, K.; D’Angelo, M.D.; Hart, C.J.R.; Hollings, P.; Gleeson, S.A.; Alfaro, M. Using zircon trace element composition to assess porphyry copper potential of the Guichon Creek batholith and highland valley Copper deposit, South-Central British Columbia. Miner. Depos. 2021, 56, 215-238. [CrossRef]

38. Zhong, S.H.; Seltmann, R.; Qu, H.Y.; Song, Y.X. Characterization of the zircon Ce anomaly for estimation of oxidation state of magmas: A revised Ce/Ce* method. Mineral. Petrol. 2019, 113, 755-763. [CrossRef]

39. Large, S.J.E.; von Quadt, A.; Wotzlaw, J.-F.; Guillong, M.; Heinrich, C.A. Magma evolution leading to porphyry Au-Cu mineralization at the Ok Tedi deposit, Papua New Guinea: Trace element geochemistry and high-precision geochronology of igneous zircon. Econ. Geol. 2018, 113, 39-61. [CrossRef]

40. Large, S.J.E.; Buret, Y.; Wotzlaw, J.F.; Karakas, O.; Guillong, M.; von Quadt, A.; Heinrich, C.A. Copper-mineralized porphyries sample the evolution of large-volume silicic magma reservoir from rapid assembly to solidification. Earth Planet. Sci. Lett. 2021, 563, 116877. [CrossRef]

41. Olson, N.H.; Dilles, J.H.; Kent, A.J.R.; Lang, J.R. Geochemistry of the Cretaceous Kaskanak Batholith and genesis of the Pebble porphyry Cu-Au-Mo deposit, Southwest Alaska. Am. Mineral. 2017, 102, 1597-1621. [CrossRef]

42. Chelle-Michou, C.; Chiaradia, M.; Ovtcharova, M.; Ulianov, A.; Wotzlaw, J.F. Zircon petrochronology reveals the temporal link between porphyry systems and the magmatic evolution of their hidden plutonic roots (the Eocene Coroccohuayco deposit, Peru). Lithos 2014, 198, 129-140. [CrossRef]

43. Loader, M.A.; Wilkinson, J.J.; Armstrong, R.N. The effect of titanite crystallisation on Eu and Ce anomalies in zircon and its implications for the assessment of porphyry Cu deposit fertility. Earth Planet. Sci. Lett. 2017, 472, 107-119. [CrossRef]

44. Kobylinski, C.; Hattori, K.; Smith, S.; Plouffe, A. Protracted magmatism and mineralized hydrothermal activity at the Gibraltar porphyry copper-molybdenum deposit, British Columbia. Econ. Geol. 2020, 115, 1119-1136. [CrossRef]

45. Smythe, D.J.; Brenan, J.M. Cerium oxidation state in silicate melts: Combined $f \mathrm{O}_{2}$, temperature and compositional effects. Geochim. Cosmochim. Acta 2015, 170, 173-187. [CrossRef]

46. Smythe, D.J.; Brenan, J.M. Magmatic oxygen fugacity estimated using zircon-melt partitioning of cerium. Earth Planet. Sci. Lett. 2016, 453, 260-266. [CrossRef]

47. Loucks, R.R.; Fiorentini, M.L.; Henriquez, G.J. New magmatic oxybarometer using trace elements in zircon. J. Petrol. $2020,61$. [CrossRef]

48. Hattori, K. Porphyry copper potential in Japan based on magmatic oxidation state. Resour. Geol. 2018, 68, 126-137. [CrossRef]

49. Dilles, J.H.; Kent, A.J.R.; Wooden, J.L.; Tosdal, R.M.; Koleszar, A.; Lee, R.G.; Farmer, L.P. Zircon compositional evidence for sulfur-degassing from ore-forming arc magmas. Econ. Geol. 2015, 110, 241-251. [CrossRef]

50. Sengör, A.M.C.; Natal'in, B.A.; Burtman, V.S. Evolution of the Altaid tectonic collage and Paleozoic crustal growth in Eurasia. Nature 1993, 364, 299-307. [CrossRef]

51. Windley, B.F.; Alexeiev, D.; Xiao, W.J.; Kröner, A.; Badarch, G. Tectonic model for accretion of the Central Asian Orogenic belt. J. Geol. Soc. Lond. 2007, 164, 31-47. [CrossRef]

52. Kröner, A.; Kovach, V.; Belousova, E.; Hegner, E.; Armstrong, R.; Dolgopolova, A.; Seltmann, R.; Alexeiev, D.V.; Hoffmann, J.E.; Wong, J.; et al. Reassessment of continental growth during the accretionary history of the Central Asian Orogenic belt. Gondwana Res. 2014, 25, 103-125. [CrossRef]

53. Xiao, W.J.; Windley, B.F.; Sun, S.; Li, J.L.; Huang, B.C.; Han, C.M.; Yuan, C.; Sun, M.; Chen, H.L. A tale of amalgamation of three Permo-Triassic collage systems in Central Asia: Oroclines, sutures, and terminal accretion. Annu. Rev. Earth Planet. Sci. 2015, 43, 477-507. [CrossRef]

54. Meng, E.; Xu, W.L.; Pei, F.P.; Yang, D.B. Detrital-zircon geochronology of late Paleozoic sedimentary rocks in eastern Heilongjiang Province, NE China: Implications for the tectonic evolution of the eastern segment of the Central Asian Orogenic belt. Tectonophysics 2010, 485, 42-51. [CrossRef]

55. Wu, F.Y.; Sun, D.Y.; Ge, W.C.; Zhang, Y.B.; Grant, M.L.; Wilde, S.A.; Jahn, B.M. Geochronology of the Phanerozoic granitoids in Northeastern China. J. Asian Earth Sci. 2011, 41, 1-30. [CrossRef] 
56. Cao, H.H.; Xu, W.L.; Pei, F.P.; Wang, Z.W.; Wang, F.; Wang, Z.J. Zircon U-Pb geochronology and petrogenesis of the late Paleozoicearly Mesozoic intrusive rocks in the eastern segment of the northern margin of the North China block. Lithos 2013, 170-171, 191-207. [CrossRef]

57. Tang, J.; Xu, W.L.; Wang, F.; Wang, W.; Xu, M.J.; Zhang, Y.H. Geochronology and geochemistry of Neoproterozoic magmatismin the Erguna massif, NE China: Petrogenesis and implications for the breakup of the Rodinia supercontinent. Precambrian Res. 2013, 224, 597-611. [CrossRef]

58. Li, Y.; Xu, W.L.; Wang, F.; Tang, J.; Pei, F.P.; Wang, Z.J. Geochronology and geochemistry of late Paleozoic volcanic rocks on the western margin of the Songnen-Zhangguangcai range massif, NE China: Implications for the amalgamation history of the Xing'an and Songnen-Zhangguangcai range massifs. Lithos 2014, 205, 394-410. [CrossRef]

59. Shen, P.; Pan, H.D.; Hattori, K.; David, R.C.; Seitmuratova, E. Large Paleozoic and Mesozoic porphyry deposits in the Central Asian Orogenic belt: Geodynamic settings, magmatic sources, and genetic models. Gondwana Res. 2018, 58, 161-194. [CrossRef]

60. Bai, L.A.; Sun, J.G.; Yong, Z.; Han, S.J.; Yang, F.C.; Men, L.J. Genetic type, mineralization epoch and geodynamical setting of endogenous copper deposits in the Great Xing'an Range. Acta Petrol. Sin. 2012, 28, 468-482. (In Chinese with English abstract)

61. Yakubchuk, A.; Degtyarev, K.; Maslennikov, V.; Wurst, A.; Stekhin, A.; Lobanov, K. Tectonomagmatic settings, architecture, and metallogeny of the Central Asian copper province. Soc. Econ. Geol. Spec. Publ. 2012, 16, 403-432.

62. Jochum, K.P.; Weis, U.; Stoll, B.; Kuzmin, D.; Yang, Q.; Raczek, I.; Gunther, D. Determination of reference values for NIST SRM 610-617 glasses following ISO guidelines. Geostand. Geoanal. Res. 2011, 35, 397-429. [CrossRef]

63. Griffin, W.L.; Powell, W.J.; Pearson, N.J.; O’Reilly, S.Y. GLITTER: Data reduction software for laser ablation ICP-MS. Laser ablation-ICP-MS in the Earth sciences. Mineral. Assoc. Can. Short Course Ser. 2008, 40, $204-207$.

64. Jackson, S.E.; Dube, B.; Chapman, J.; Gao, J.F. Applications of LA-ICP-MS element mapping in mineral deposit research and exploration: Mineral deposit research for a high-tech world. In Proceedings of the 12th SGA Biennial Meeting, Uppsala, Sweden, 12-15 August 2013; Volume 1, pp. 201-204.

65. Middlemost, E.A.K. Naming materials in the magma/igneous rock system. Earth Sci. Rev. 1994, 37, 215-224. [CrossRef]

66. Du, Q.; Ma, X.Y.; Han, C.M.; Jiang, X.L. Genetic Discussion on Porphyry Copper Deposit; Geological Publishing House: Beijing, China, 2008. (In Chinese)

67. Peccerillo, A.; Taylor, S.R. Geochemistry of Eocene calc-alkaline volcanic rocks from the Kastamonu area, Northern Turkey. Contrib. Mineral. Petrol. 1976, 58, 68-81. [CrossRef]

68. Defant, M.J.; Drummond, M.S. Derivation of some modern arc magmas by melting of young subducted lithosphere. Nature 1990, 347, 662-665. [CrossRef]

69. McDonough, W.; Sun, S. The composition of the Earth. Chem. Geol. 1995, 120, 223-253. [CrossRef]

70. Ferry, J.M.; Watson, E.B. New thermodynamic models and revised calibrations for the Ti-in-zircon and Zr-in-rutile thermometers. Contrib. Mineral. Petrol. 2007, 154, 429-437. [CrossRef]

71. Hayden, L.A.; Watson, E.B. Rutile saturation in hydrous siliceous melts and its bearing on Ti thermometry of quartz and zircon. Earth Planet. Sci. Lett. 2007, 258, 561-568. [CrossRef]

72. Fu, B.; Page, F.Z.; Cavosie, A.J.; Clechenko, C.C.; Fournelle, J.; Kita, N.T.; Lackey, J.S.; Wilde, S.A.; Valley, J.W. Ti-in-zircon thermometry: Applications and limitations. Contrib. Mineral. Petrol. 2008, 156, 197-215. [CrossRef]

73. Watson, E.B.; Harrison, T.M. Zircon saturation revisited: Temperature and composition effects in a variety of crustal magma types. Earth Planet. Sci. Lett. 1983, 64, 295-304. [CrossRef]

74. Trail, D.; Watson, E.B.; Tailby, N.D. Ce and Eu anomalies in zircon as proxies for the oxidation state of magmas. Geochim. Cosmochim. Acta 2012, 97, 70-87. [CrossRef]

75. Ridolfi, F.; Renzulli, A.; Puerini, M. Stability and chemical equilibrium of amphibole in calc-alkaline magmas: An overview, new thermobarometric formulations and application to subduction-related volcanoes. Contrib. Mineral. Petrol. 2010, 160, 45-66. [CrossRef]

76. Blundy, J.; Wood, B. Prediction of crystal-melt partition coefficients from elastic moduli. Nature 1994, 372, 452-454. [CrossRef]

77. Garwin, S.L. The Setting, Geometry and Timing of Intrusion-Related Hydrothermal Systems in the Vicinity of the Batu Hijau Porphyry Copper-Gold Deposit, Sumbawa, Indonesia. Ph.D. Thesis, University of Western Australia, Nedlands, Australia, 2000; p. 320 .

78. Rohrlach, B.D.; Loucks, R.R. Multi-million-year cyclic ramp-up of volatiles in a lower crustal magma reservoir trapped below the Tampakan copper-gold deposit by Mio-Pliocene crustal compression in the southern Philippines. In Super Porphyry Copper and Gold Deposits-A Global Perspective; Porter, T.M., Ed.; PCG Publishing: Adelaide, Australia, 2005; Volume 2, pp. $369-407$.

79. Holtz, F.; Johannes, W.; Tamic, N.; Behrens, H. Maximum and minimum water contents of granitic melts generated in the crust: A re-evaluation and implications. Lithos 2001, 56, 1-14. [CrossRef]

80. Miao, L.C.; Fan, W.M.; Zhang, F.Q.; Liu, D.Y.; Jian, P.; Shi, G.H.; Tao, H.; Shi, Y.R. Zircon SHRIMP geochronology of the Xinkailing-Kele complex in the northwestern lesser Xing'an range, and its geological implications. Chin. Sci. Bull. 2004, 49, 201-209. [CrossRef]

81. Zhou, M.F.; Zhang, H.F.; Robinson, P.T.; Malpas, J. Comments on "Petrology of the Hegenshan ophiolite and its implication for the tectonic evolution of northern China" by T. Nozaka and Y. Liu [Earth Planet. Sci. Lett. 202 (2002) 89-104]. Earth Planet. Sci. Lett. 2004, 217, 207-210. [CrossRef] 
82. Grimes, C.B.; Wooden, J.L.; Cheadle, M.J.; John, B.E. “Fingerprinting" tectono-magmatic provenance using trace elements in igneous zircon. Contrib. Mineral. Petrol. 2015, 170, 46. [CrossRef]

83. Grimes, C.B.; John, B.E.; Kelemen, P.B.; Mazdab, F.; Wooden, J.L.; Cheadle, M.J.; Hanghøj, K.; Schwartz, J.J. The trace element chemistry of zircons from oceanic crust: A method for distinguishing detrital zircon provenance. Geology 2007, 35, 643-646. [CrossRef]

84. Gao, S.; Rudnick, R.L.; Yuan, H.L.; Liu, X.M.; Liu, Y.S.; Xu, W.L.; Ling, W.L.; Ayers, J.; Wang, X.C.; Wang, Q.H. Recycling lower continental crust in the North China craton. Nature 2004, 432, 892-897. [CrossRef]

85. Chung, S.L.; Liu, D.Y.; Ji, J.Q.; Chu, M.F.; Lee, H.Y.; Wen, D.R.; Lo, C.H.; Lee, T.Y.; Qian, Q.; Zhang, Q. Adakites from continental collision zones: Melting of thickened lower crust beneath southern Tibet. Geology 2003, 31, 1021-1024. [CrossRef]

86. Guan, Q.; Zhu, D.C.; Zhao, Z.D.; Dong, G.C.; Zhang, L.L.; Li, X.W.; Liu, M.; Mo, X.X.; Liu, Y.S.; Yuan, H.L. Crustal thickening prior to 38Ma in southern Tibet: Evidence from lower crust-derived adakitic magmatism in the Gangdese batholith. Gondwana Res. 2012, 21, 88-99. [CrossRef]

87. Long, X.P.; Wilde, S.A.; Wang, Q.; Yuan, C.; Wang, X.C.; Li, J.; Dan, W. Partial melting of thickened continental crust in central Tibet: Evidence from geochemistry and geochronology of Eocene adakitic rhyolites in the Northern Qiangtang terrane. Earth Planet. Sci. Lett. 2015, 414, 30-44. [CrossRef]

88. Richards, J.P.; Kerrich, R. Adakite-like rocks: Their diverse origins and questionable role in metallogenesis. Econ. Geol. 2007, 102, 537-576. [CrossRef]

89. Wang, R.; Richards, J.P.; Hou, Z.Q.; Yang, Z.M.; DuFrane, S.A. Increased magmatic water content-The key to Oligo-Miocene porphyry Cu-Mo \pm Au formation in the eastern Gangdese belt, Tibet. Econ. Geol. 2014, 195, 1315-1339. [CrossRef]

90. Lu, Y.J.; Loucks, R.R.; Fiorentini, M.L.; Yang, Z.M.; Hou, Z.Q. Fluid flux melting generated post-collisional high Sr/Y copper ore-forming water-rich magmas in Tibet. Geology 2015, 43, 583-586. [CrossRef]

91. Wang, J.; Hattori, K.; Liu, J.G.; Song, Y.; Gao, Y.B.; Zhang, H. Shoshonitic- and adakitic magmatism of the early Paleozoic age in the western Kunlun orogenic belt, NW China: Implications for the early evolution of the northwestern Tibetan plateau. Lithos 2017, 286-287, 345-362. [CrossRef]

92. Wang, Q.; Wyman, D.A.; Xu, J.F.; Zhao, Z.H.; Jian, P.; Xiong, X.L.; Bao, Z.W.; Li, C.F.; Bai, Z.H. Petrogenesis of Cretaceous adakitic and shoshonitic igneous rocks in the Luzong area, Anhui province (Eastern China): Implications for geodynamics and $\mathrm{Cu}-\mathrm{Au}$ mineralization. Lithos 2006, 89, 424-446. [CrossRef]

93. Rollinson, H. Using Geochemical Data: Evaluation, Presentation, Interpretation; Longman: Harlow, UK, 1993 ; p. 352.

94. Sisson, T.W. Hornblende-melt trace-element partitioning measured by ion microprobe. Chem. Geol. 1994, 117, 331-344. [CrossRef]

95. Moore, G.; Carmichael, I.S.E. The hydrous phase equilibria (to $3 \mathrm{kbar}$ ) of an andesite and basaltic andesite from Western Mexico: Constraints on water content and conditions of phenocryst growth. Contrib. Mineral. Petrol. 1998, 130, 304-319. [CrossRef]

96. Bachmann, O.; Dungan, M.A.; Bussy, F. Insights into shallow magmatic processes in large silicic magma bodies: The trace element record in the Fish canyon magma body, Colorado. Contrib. Mineral. Petrol. 2005, 149, 38-349. [CrossRef]

97. Prowatke, S.; Klemme, S. Trace element partitioning between apatite and silicate melts. Geochim. Cosmochim. Acta 2006, 70, 4513-4527. [CrossRef]

98. Viala, M.; Hattori, K. Hualgayoc mining district, northern Peru: Testing the use of zircon composition in exploration for porphyry-type deposits. J. Geochem. Explor. 2021, 223, 106725. [CrossRef]

99. Richards, J.P. Giant ore deposits formed by optimal alignments and combinations of geological processes. Nat. Geosci. 2013, 6, 911-916. [CrossRef]

100. Wainwright, A.J.; Tosdal, R.M.; Wooden, J.L.; Mazdab, F.K.; Friedman, R.M. U-Pb (zircon) and geochemical constraints on the age, origin, and evolution of Paleozoic arc magmas in the Oyu Tolgoi porphyry Cu-Au district, southern Mongolia. Gondwana Res. 2011, 19, 764-787. [CrossRef]

101. Chelle-Michou, C.; Chiaradia, M.; Béguelin, P.; Ulianov, A. Petrological evolution of the magmatic suite associated with the coroccohuayco Cu (-Au-Fe) porphyry-skarn deposit, Peru. J. Petrol. 2015, 56, 1829-1862. [CrossRef]

102. Wang, G.G.; Ni, P.; Yao, J.; Wang, X.L.; Zhao, K.D.; Zhu, R.Z.; Xu, Y.F.; Pan, J.Y.; Li, L.; Zhang, Y.H. The link between subductionmodified lithosphere and the giant Dexing porphyry copper deposit, South China: Constraints from high-Mg adakitic rocks. Ore Geol. Rev. 2015, 67, 109-126. [CrossRef]

103. Jiang, Y.H.; Jiang, S.Y.; Ling, H.F.; Dai, B.Z. Low-degree melting of a metasomatized lithospheric mantle for the origin of Cenozoic Yulong monzogranite-porphyry, east Tibet: Geochemical and Sr-Nd-Pb-Hf isotopic constraints. Earth Planet. Sci. Lett. 2006, 241, 617-633. [CrossRef]

104. Li, J.X.; Qin, K.Z.; Li, G.M.; Cao, M.J.; Xiao, B.; Chen, L.; Zhao, J.X.; Evans, N.J.; McInnes, B.I.A. Petrogenesis and thermal history of the Yulong porphyry copper deposit, Eastern Tibet: Insights from U-Pb and U-Th/He dating, and zircon Hf isotope and trace element analysis. Mineral. Petrol. 2012, 105, 201-221. [CrossRef]

105. Cooke, D.R.; Hollings, P.; Walshe, J.L. Giant porphyry deposits: Characteristics, distribution, and tectonic controls. Econ. Geol. 2005, 100, 801-818. [CrossRef]

106. Muñoz, M.; Charrier, R.; Fanning, C.M.; Maksaev, V.; Deckart, K. Zircon trace element and O-Hf isotope analyses of mineralized intrusions from El Teniente ore deposit, Chilean Andes: Constraints on the source and magmatic evolution of porphyry Cu-Mo related magmas. J. Petrol. 2012, 53, 1091-1122. [CrossRef] 
107. Nardi, L.V.S.; Formoso, M.L.L.; Jarvis, K.; Oliveira, L.; Nato, A.C.B.; Fontana, E. REE, Y, Nb, U and Th contents and tetrad effect in zircon from a magmatic-hydrothermal F-rich system of Sn-rare metal-cryolite mineralized granites from the Pitinga mine, Amazonia, Brazil. J. S. Am. Sci. 2012, 33, 34-42. [CrossRef]

108. Belousova, E.A.; Griffin, W.L.; O’Reilly, S.Y.; Fisher, N.I. Igneous zircon: Trace element compositions as an indicator of source rock type. Contrib. Mineral. Petrol. 2002, 143, 602-622. [CrossRef]

109. Lu, Y.J.; Loucks, R.R.; Fiorentini, M.L.; McCuaig, T.C.; Evans, N.J.; Yang, Z.M.; Hou, Z.Q.; Kirkland, C.L.; Parra-Avila, L.A.; Kobussen, A. Zircon composition as a pathfinder for porphyry $\mathrm{Cu} \pm \mathrm{Mo} \pm \mathrm{Au}$ deposits in tectonics and metallogeny of the Tethyan Orogenic belt. Soc. Econ. Geol. 2016, 19, 329-347.

110. Wones, D.R. Significance of the assemblage titanite + magnetite + quartz in granitic rocks. Am. Mineral. 1989, 74, 744-749.

111. Hattori, K.; Keith, J.D. Contribution of mafic melt to porphyry copper mineralization: Evidence from mount Pinatubo, Philippines, and Bingham canyon, Utah, USA. Miner. Depos. 2001, 36, 799-806. [CrossRef]

112. DeHoog, J.C.M.; Hattori, K.H.; Hoblitt, R.P. Oxidized sulfur-rich mafic magma at mount Pinatubo, Philippines. Contrib. Mineral. Petrol. 2004, 146, 750-761. [CrossRef]

113. Wang, J.; Hattori, K.H.; Kilian, R.; Stern, C.R. Metasomatism of sub-arc mantle peridotites below southern South America: Reduction of $\mathrm{fO}_{2}$ by slab-melt. Contrib. Mineral. Petrol. 2007, 153, 607-624. [CrossRef]

114. Wood, B.J.; Bryndzia, L.T.; Johnson, K.E. Mantle oxidation state and its relationship to tectonic environment and fluid speciation. Science 1990, 248, 337-345. [CrossRef]

115. Ballhaus, C. Redox states of lithospheric and asthenospheric upper mantle. Contrib. Mineral. Petrol. 1993, 114, 331-348. [CrossRef]

116. Arai, S.; Ishimaru, S. Insights into petrological characteristics of the lithosphere of mantle wedge beneath Arcs through peridotite xenoliths: A review. J. Petrol. 2008, 49, 665-695. [CrossRef]

117. Wang, J.; Hattori, K.; Xie, Z.P. Oxidation state of lithospheric mantle along the northeastern margin of the North China craton: Implications for geodynamic processes. Int. Geol. Rev. 2013, 55, 1418-1444. [CrossRef]

118. Candela, P.A. Controls on ore metal ratios in granitoid-related ore systems: An experimental and computational approach. Trans. R. Soc. Edinb. Earth Sci. 1992, 83, 317-326.

119. Field, C.W.; Zhang, L.; Dilles, J.H.; Rye, R.O.; Reed, M.H. Sulfur and oxygen isotopes of pre-main stage porphyry Cu-Mo and late shallow main stage base mineral deposits, Butte district, Montana. Chem. Geol. 2005, 215, 61-93. [CrossRef]

120. Rye, R.O. A review of the stable-isotope geochemistry of sulfate minerals in selected igneous environments and related hydrothermal systems. Chem. Geol. 2005, 215, 5-36. [CrossRef]

121. Chambefort, I.; Dilles, J.H.; Kent, A.J.R. Anhydrite-bearing andesite and dacite as a source for sulfur in magmatic-hydrothermal mineral deposits. Geology 2008, 36, 719-722. [CrossRef]

122. Chambefort, I.; Dilles, J.H.; Longo, A.A. Amphibole geochemistry of the Yanacocha volcanics, Peru: Evidence for diverse sources of magmatic volatiles related to gold ores. J. Petrol. 2013, 54, 1017-1046. [CrossRef]

123. Loucks, R.R. Distinctive composition of copper-ore-forming arc magmas. Aust. J. Earth Sci. 2014, 61, 5-16. [CrossRef]

124. Richards, J.P. The oxidation state, and sulfur and Cu contents of arc magmas: Implications for metallogeny. Lithos 2015, 233, 27-45. [CrossRef]

125. Carroll, M.K.; Rutherford, M.J. Sulfur speciation in hydrous experimental glasses of varying oxidation state-results from measured wavelength shifts of sulfur X-rays. Am. Mineral. 1988, 73, 845-849.

126. Hedenquist, J.W.; Lowenstern, J.B. The role of magmas in the formation of hydrothermal ore deposits. Nature 1994, 370, 519-527. [CrossRef]

127. Urich, T.; Guenther, D.; Heinrich, C.A. Gold concentrations of magmatic brines and the metal budget of porphyry copper deposits. Nature 1999, 399, 676-679. [CrossRef] 